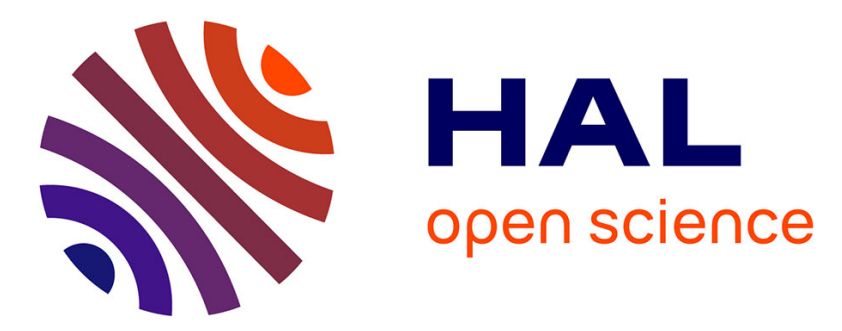

\title{
A lipoxygenase with linoleate diol synthase activity from Nostoc sp. PCC 7120
}

Imke Lang, Cornelia Göbel, Andrea Porzel, Ingo Heilmann, Ivo Feussner

\section{To cite this version:}

Imke Lang, Cornelia Göbel, Andrea Porzel, Ingo Heilmann, Ivo Feussner. A lipoxygenase with linoleate diol synthase activity from Nostoc sp. PCC 7120. Biochemical Journal, 2008, 410 (2), pp.347-357. 10.1042/BJ20071277 . hal-00478884

\section{HAL Id: hal-00478884 \\ https://hal.science/hal-00478884}

Submitted on 30 Apr 2010

HAL is a multi-disciplinary open access archive for the deposit and dissemination of scientific research documents, whether they are published or not. The documents may come from teaching and research institutions in France or abroad, or from public or private research centers.
L'archive ouverte pluridisciplinaire HAL, est destinée au dépôt et à la diffusion de documents scientifiques de niveau recherche, publiés ou non, émanant des établissements d'enseignement et de recherche français ou étrangers, des laboratoires publics ou privés. 


\section{A Lipoxygenase with Linoleate Diol Synthase Activity from Nostoc sp. PCC 7120}

\section{Imke Lang*, Cornelia Göbel ${ }^{*}$, Andrea Porzel ${ }^{\dagger}$, Ingo Heilmann* and Ivo Feussner}

*Department of Plant Biochemistry, Albrecht-von-Haller-Institute for Plant Sciences, GeorgAugust-University, 37077 Goettingen, Germany

${ }^{\dagger}$ Department for Bioorganic Chemistry, Leibnitz-Institute of Plant Biochemistry (IPB), 06120 Halle/Saale, Germany.

Address correspondence to: Ivo Feussner, Georg-August-University, Albrecht-von-HallerInstitute for Plant Sciences, Department of Plant Biochemistry, Justus-von-Liebig Weg 11, 377077 Goettingen, Germany. Phone: +49 551 395743, Fax: +49 551 395749, E-mail: ifeussn@gwdg.de 


\section{Synopsis}

The dioxygenation of polyunsaturated fatty acids in plants is mainly catalyzed by members of the lipoxygenase enzyme family. Lipoxygenase products may be further metabolized and are known as signalling substances in plant development and in responses to wounding and pathogen attack. In contrast to the situation in eukaryotes, information on the relevance of lipidperoxide metabolism in prokaryotic organisms is scarce. Therefore, we aimed to analyze lipoxygenases and oxylipin patterns of cyanobacterial origin. A search of the genomic sequence of the cyanobacterium, Nostoc sp. PCC 7120, suggested an open reading frame encoding a putative lipoxygenase named NspLOX that harboured an amino-terminal extension. Individual analysis of recombinant carboxy-terminal domain revealed enzymatic activity as a linoleate (9R)-lipoxygenase. Analysis of the full-length NspLOX-protein however, revealed linoleate diol synthase activity, generating (10E,12E)-9,14-dihydroxy10,12-octadecadienoic acid as the main product from linoleic acid and (10E,12E,14E)-9,16dihydroxy-10,12,14-octadecatrienoic acid as the main product from $\alpha$-linolenic acid substrates, respectively, with $\alpha$-linolenic acid as preferred substrate. The enzyme exhibited a broad $\mathrm{pH}$ optimum between $\mathrm{pH} 7$ and 10. Soluble extracts of Nostoc sp. contain more 9lipoxygenase-derived hydroperoxides in sonified than in non-sonified cells, but products of full-length NspLOX were not detectable under the conditions used. As no other lipoxygenaselike sequence was identified in the genome of Nostoc sp. PCC 7120, the results presented suggest that $(9 R)$-lipoxygenase-derived oxylipins may represent the endogenous products of NspLOX. Based on the biochemical data of NspLOX we suggest that this bifunctional enzyme may represent a more ancient way to control the intracellular amount of oxylipins in this cyanobacterium.

Short title Linoleate Diol Synthase from Nostoc sp. 
Abbreviations AA, arachidonic acid; ALA, $\alpha$-linolenic acid; AOS, allene oxide synthase; CP-HPLC, chiral phase-HPLC; diHODE, dihydroxy octadecadienoic acid; GC, gas chromatography; GLA, $\gamma$-linolenic acid; H(P)ETE, hydro(pero)xy eicosatetraenoic acid; H(P)ODE, hydro(pero)xy octadecadienoic acid; H(P)OTE, hydro(pero)xy octadecatrienoic acid; LA, linoleic acid; LOX, lipoxygenase; PUFA, polyunsaturated fatty acid; RP-HPLC, reversed phase-HPLC; SAG, Sammlung für Algenkulturen Goettingen; SP-HPLC, straight phase-HPLC.

Keywords Bifunctional enzyme, Cyanobacteria, Oxylipins, Prokaryotic lipoxygenase 


\section{INTRODUCTION}

Eukaryotic algae have developed mechanisms involving lipidperoxidation by which they defend themselves against abiotic and biotic stresses [1]. One of these mechanisms relates to the induction of the so-called lipoxygenase (LOX) pathway $[1,2]$. This metabolic pathway is well-characterized from flowering plants and involved in the production of hormones and defensive metabolites [3]. The products synthesized by the LOX-pathway are collectively named oxylipins [4]. The first committed step of the pathway is the LOX reaction and the resulting oxidation products serve as substrates for the synthesis of a large variety of oxylipins that are synthesized in plants by at least six different enzyme families [5]. LOX enzymes represent a family of non-heme iron-containing fatty acid dioxygenases, which catalyze the stereospecific insertion of molecular oxygen into polyunsaturated fatty acids (PUFAs), leading to the formation of hydroperoxy fatty acids [6]. LOXs are widely distributed in nature and occur ubiquitously in plants and mammals [7,8]. In recent years successful cloning of genes encoding LOXs from coral, moss, and bacteria, has been reported and expands our current knowledge on the occurrence of this class of enzymes [9-13]. However knowledge on the biological function of the enzymes in prokaryotes is still scarce.

In plants, LOXs are classified with respect to their positional specificity of fatty acid oxygenation against linoleic acid (LA). LA is oxygenated either at carbon atom 9 (9-LOX) or at C-13 (13-LOX) of the hydrocarbon backbone, which leads to the formation of 9hydroperoxy- and 13-hydroperoxy derivatives of LA (9- and 13-HPODE), respectively. In mammals LOXs are classified according to their positional specificity of arachidonic acid (AA) oxygenation. This PUFA can be oxygenated by LOXs at six different positions: C-5 (5LOX), C-8 (8-LOX), C-9 (9-LOX), C-11 (11-LOX), C-12 (12-LOX) and C-15 (15-LOX), respectively [14]. All of the LOX-derived fatty acid hydroperoxides are formed with high chiral purity [6]. The prototypical LOXs produce fatty acid hydroperoxides in $S$ configuration, 
however, a few enzymes have been described that produce $R$-configurated products $[9,15,16]$. Interestingly, in the cyanobacterium Anabaena flos-aquae f. flos aquae two different hydroxy fatty acids in $R$-configuration have been isolated, (9R)-HPODE and (9R)-hydroperoxy linolenic acid ((9R)-HPOTE), suggesting cyanobacteria may contain as well a $(9 R)$-LOX [17].

As the corresponding cyanobacterial enzyme has not been identified in Anabaena, a search of the accessible genomic sequence of the related filamentous cyanobacterium, Nostoc sp. PCC 7120, was conducted in order to identify open reading frames with similarity to known LOX-sequences. A single sequence was identified and named NspLOX, which was found to encode a LOX harbouring a large amino-terminal extension and exhibits highest similarity to a peroxidase-LOX fusion-protein from the coral Plexaura homomalla [18]. The previously reported coral enzyme consists of two distinct domains that have been demonstrated individually to exhibit different catalytic activities, the amino-terminal domain as an allene oxide synthase (AOS), and the carboxy-terminal domain as an (8R)-LOX [19]. In case of the coral fusion-protein the LOX domain converted AA to its corresponding $(8 R)$ hydroperoxide $((8 R)$-HPETE), while the AOS-domain metabolized (8R)-HPETE to an unstable allene oxide which hydrolyzes spontaneously into $\alpha$ - and $\gamma$-ketols and cyclopentanone derivatives. The LOX protein from N. sp. PCC 7120 has a domain structure similar to that of its coral equivalent, suggesting a common origin in evolution.

\section{EXPERIMENTAL}

\section{Algae Cultures}

For the characterisation of NspLOX Nostoc sp. PCC 7120 (obtained as SAG 25.82 from the Sammlung für Algenkulturen in Goettingen (SAG)) was cultivated in liquid BG 11 medium according to http://www.epsag.uni-goettingen.de/html/sag.html at $20^{\circ} \mathrm{C}$ in 11 conical flasks 
shaking at $120 \mathrm{rpm}$. For the analysis of oxylipins in vivo two additional strains, PCC $7120 \mathrm{P}$ and PCC 7120 A, were obtained from Prof. Peter Wolk, Michigan State University, East Lansing, MI, USA and Prof. James Golden, Texas A\&M University, College Station, TX, USA, respectively and cultivated under the identical conditions. After 3 weeks of cultivation, cells were harvested by centrifugation at $3220 \mathrm{x} \mathrm{g}$ for $10 \mathrm{~min}$ and pellets were stored at $20{ }^{\circ} \mathrm{C}$.

\section{Isolation and Expression of Separate Domains and Entire Protein of NspLOX}

Genomic DNA was isolated from approximately $50 \mathrm{mg}$ of frozen cell material from $N$. sp. SAG 25.82 using the NucleoSpin ${ }^{\circledR}$ Plant kit (Macherey-Nagel) according to manufacturer's instructions. The gene fragment encoding the LOX-domain was isolated by PCR using the primer-combination LOXFNdeI (5'-ACATATGCAGTATTTGTATGGAAGTAAAGG3')/LOXRBglII (5'-AAGATCTCTAAATGTTGATACTCATCATGAG-3'). The DNAsequence encoding the putative peroxidase domain was isolated by PCR using the primercombination KatFNdeI (5'-ACATATGGATTTGAATACTTACTTGAAG-3')/KatRBglII (5'AAGATCTTTTTCCAGGCAAATCATCCTTAC-3'). Amplicons were cloned into pGEM-T (Promega) and moved âs NdeI/Bglil fragments into the expression vector pET15b, introducing an amino-terminal His-Tag (Novagene). The constructs were transformed into $E$. coli Rosetta(DE3) cells. . The entire gene encoding NspLOX was amplified using the primercombination KatFNdeI (5'-ACATATGGATTTGAATACTTACTTGAAG-3')/LOXRBglII (5'-AAGATCTCTAAATGTTGATACTCATCATGAG-3'). The fragment initially obtained from SAG 25.82 contained an insertion of $1300 \mathrm{bp}$ within the amino-terminal domain, which was removed by PCR mutagenesis as follows. The DNA-stretches encoding the individual amino-terminal and carboxy-terminal domains were amplified with chimeric primers flanking the insertion site: KatFNdeI (5'-ACATATGGATTTGAATACTTACTTGAAG-3')/ChimR (5'-GTAAACGAATCTGGATTGCGTAAGGCTGCCTCCAC-3') for exon 1 and ChimF (5' 
AAGATCTCTAAATGTTGATACTCATCATGAG-3') for exon 2. DNA-fragments were then combined for the fusion reaction. After 12 PCR cycles an aliquot $(1: 200)$ of the fused fragments was used as a template for amplification of the fusion product with primers KatFNdeI and LOXRBglII. The obtained NspLOX fragment was purified using the DNA and Gel Band Purification Kit (GE Healthcare) according to manufacturer's instructions. Subsequently, the fragment was cloned directly into the expression system $\mathrm{pCR}^{\circledR} \mathrm{T} 7 / \mathrm{TOPO}^{\circledR} \mathrm{NT}$ vector (Invitrogen), introducing an amino-terminal His-Tag, and this construct was transformed into E. coli BL21(DE3) cells.

Expression cultures were grown in $30 \mathrm{ml} \mathrm{LB}$ medium at $37^{\circ} \mathrm{C}$ until they reached $\mathrm{OD}_{600}$ 0.6 [20]. Then $50 \mu \mathrm{l}$ of $1 \mathrm{M}$ IPTG was added and the cultures were further incubated at $16^{\circ} \mathrm{C}$ over night. E. coli expression cultures were harvested by centrifugation at $3220 \mathrm{xg}$ at $4{ }^{\circ} \mathrm{C}$ for $20 \mathrm{~min}$.

\section{Activity Assays}

For activity assays the pellets of expression cultures were resuspended in $2 \mathrm{ml}$ lysis buffer (50 mM Tris, pH 8.0, $150 \mathrm{mM} \mathrm{NaCl}, 10 \%$ (w/w) Glycerol, 0.1\% (v/v) Tween20). Cells were disrupted by 2 pulses of $20 \mathrm{~s}$ of sonification on ice and then centrifuged at $3220 \mathrm{xg}$ for $10 \mathrm{~min}$ at $4 \mathrm{C}$. A $500 \mu \mathrm{l}$ aliquot of the supernatant was added to $1.5 \mathrm{ml}$ of $50 \mathrm{mM}$ Tris buffer, $\mathrm{pH}$ 8.0. Reactions were started by adding $250 \mu \mathrm{g}$ of fatty acids, and were allowed to proceed for $30 \mathrm{~min}$ on ice. Carboxy-terminal portion: Hydroperoxides formed were reduced to their corresponding hydroxides with $2 \mathrm{ml}$ of $50 \mathrm{mM} \mathrm{SnCl}_{2}$, dissolved in methanol. After acidification to $\mathrm{pH} 3.0$ with glacial acetic acid, fatty acids were extracted and analyzed as described [21]. Amino-terminal portion: The activity was either tested with $612 \mathrm{kBq}$ of radiolabelled $\left[1-{ }^{14} \mathrm{C}\right]-(9 S)-H P O D E$ or with $(9 R)$-HPODE. The reaction was stopped by adding $2 \mathrm{ml}$ diethyl ether and $1 \mathrm{ml}$ water. After acidification to $\mathrm{pH} 3.0$ with glacial acetic acid the samples 
were centrifuged $\left(3220 \times \mathrm{g}, 5 \mathrm{~min}, 4^{\circ} \mathrm{C}\right)$, the upper phase was used for further analysis and the products were analyzed as described [11]. NspLOX: The reaction and analysis conditions were as for the LOX domain.

For the determination of the $\mathrm{pH}$ optimum of the carboxy-terminal portion and the fulllength protein, pellets of expression cultures were used. The activity was determined by monitoring LA dependent $\mathrm{O}_{2}$ consumption with an oxygen electrode (Rank Borther, Bottisham). The reaction mixture contained $900 \mu \mathrm{l}$ of either $50 \mathrm{mM}$ Tris/ $\mathrm{HCl}$ or $50 \mathrm{mM}$ sodium borate buffer ranging from $\mathrm{pH} 4.0$ to 12.0 , and $100 \mu \mathrm{l}$ of supernatant in a total volume of $1 \mathrm{ml}$. Reactions were started by adding $10 \mu \mathrm{l}$ of $10 \mathrm{mM}$ sodium linoleate.

\section{NspLOX Activity Assay in the Presence either of ${ }^{18} \mathrm{O}_{2}$ or $\mathrm{H}_{2}{ }^{18} \mathrm{O}$}

In the first case $1.5 \mathrm{ml}$ of $50 \mathrm{mM}$ Tris $\mathrm{HCl}, \mathrm{pH} 8.0$, were degassed and buffers were enriched with ${ }^{18} \mathrm{O}_{2}$ (Campro Scientific) by continuous gas flow through the liquid for $5 \mathrm{~min}$. The supernatant of an expression culture was added to an equal volume of ${ }^{18} \mathrm{O}_{2}$-saturated buffer. The mixture was incubated for 30 min on ice with $250 \mu \mathrm{g}$ LA as substrate. During incubation the reaction mix was further enriched with ${ }^{18} \mathrm{O}_{2}$ by continuous gas flow through the liquid $(\sim 10 \mathrm{ml})$. The reaction was stopped by adding $2 \mathrm{ml}$ diethyl ether, and LOX-reaction products were analysed as described [11].

In the second case the pellet of an expression culture was resuspended in $500 \mu 1 \mathrm{H}_{2}{ }^{18} \mathrm{O}$ (Chemotrade) and the cells were disrupted via sonification as described. The crude extract was centrifuged at $3220 \times \mathrm{g}$ for $5 \mathrm{~min}$ at $4{ }^{\circ} \mathrm{C}$ and the supernatant transferred into a $15 \mathrm{ml}$ glass tube. The reaction was started by adding $250 \mu \mathrm{g}$ LA and allowed to proceed for $30 \mathrm{~min}$ on ice. The reaction was stopped by adding $2 \mathrm{ml}$ diethyl ether, and LOX-reaction products were analysed as described [11]. 


\section{Determination of Oxylipins Formed under In Vivo Conditions}

Three $100 \mathrm{ml}$ cultures of each cyanobacterial strain (PCC 7120, PCC $7120 \mathrm{~A}$, and PCC $7120 \mathrm{P}$ ) were harvested and the pellets each resuspended in $1 \mathrm{ml}$ of $50 \mathrm{mM}$ Tris $\mathrm{HCl}, \mathrm{pH}$ 8.0. Two samples of each strain were stressed by sonification for $40 \mathrm{~s}$ on ice (about $20 \%$ of cells were lysed by this treatment). Then to one stressed sample of each strain either $250 \mu \mathrm{g}$ LA or 5.5 MBq of radio-labelled $\left[1-{ }^{14} \mathrm{C}\right]-\mathrm{LA}$ was added. Samples were incubated for $30 \mathrm{~min}$ at room temperature, and reaction products were extracted and analysed as described below.

\section{Analysis of Fatty Acids, Hydroxy and Hydroperoxy Fatty Acids}

For the analysis of the fatty acid profile of $N$. sp. the lyophilised algal material was extracted by adding $405 \mu \mathrm{l}$ of methanol/toluol 2:1 (v/v) followed by homogenising the cells for $30 \mathrm{~s}$. An internal standard (10 $\mu \mathrm{g}$ of tripentadecanoate) was added. Transesterification of lipid bound fatty acids to their corresponding methyl esters was accomplished by adding $150 \mu 1$ sodium methoxide. After $20 \mathrm{~min}$ shaking at room temperature the fatty acid methyl esters were extracted twice with $500 \mu \mathrm{ln}$-hexane and $500 \mu \mathrm{l} 1 \mathrm{M} \mathrm{NaCl}$. The hexane phases were transferred into a $1.5 \mathrm{ml}$ tube, dried under streaming nitrogen, redissolved in $10 \mu \mathrm{l}$ acetonitrile and analysed as described [11]. Dihydroxy fatty acids were separated from monohydroxy FAs by a RP-HPLC gradient with a combination of the following solvents: A: 50:50:0.1 acetonitrile:water:acetic acid (v/v/v) and B: 100:0.1 acetonitrile:acetic acid (v/v). The gradient elution profile was as follows starting with a flow rate of $0.18 \mathrm{ml} / \mathrm{min}: 0-10 \mathrm{~min}, 100 \% \mathrm{~A} ; 10$ $20 \mathrm{~min}$ from $100 \% \mathrm{~A}$ to $0 \% \mathrm{~A}$ and $100 \% \mathrm{~B} ; 20-22 \mathrm{~min}$ flow rate increasing from $0.18 \mathrm{ml} / \mathrm{min}$ to $0.36 \mathrm{ml} / \mathrm{min} ; 22-27 \mathrm{~min} 100 \% \mathrm{~B} ; 27-32 \mathrm{~min}$ from $100 \% \mathrm{~B}$ to $100 \% \mathrm{~A}, 32 \mathrm{~min}-35 \mathrm{~min}$ $100 \%$ A. Oxylipin analysis was performed as described [11]. 


\section{Mass-Spectrometric Identification of Compounds}

Reaction products were further analyzed using a MS Surveyor HPLC system equipped with a photo diode array detector and coupled to a LCQ Advantage electrospray ionisation ion trap mass spectrometer (Thermo Finnigan). The NspLOX protein products were separated by RPHPLC (EC 250/2 Nucleodure 100-5 C18ec column, $250 \times 2.1 \mathrm{~mm}, 5 \mu \mathrm{m}$ particle size, Macherey-Nagel). Solvents and also the gradient were the same as above. The mass spectrometer was operated in negative mode with the source voltage set to $4 \mathrm{kV}$ and a capillary voltage of $27 \mathrm{~V}$ of a temperature of $300^{\circ} \mathrm{C}$. In full scan mode, scans were collected between $\mathrm{m} / \mathrm{z}$ values of 50 and 400 , according to [22]. To gain more structural information mono- and dihydroxy fatty acids prepared by HPLC were methylated with diazomethane (Sigma) and silylated with bis-(trimethylsilyl)trifluoroacetamide (Pierce) and analyzed by GC/MS as described [23].

\section{Structural Analysis by NMR}

The 1D and 2D NMR spectra were recorded on a Varian Inova 500 spectrometer at $499.799 \mathrm{MHz}$ $\left({ }^{1} \mathrm{H}\right)$ using $\mathrm{CDCl}_{3}$ as deuterated solvent. ${ }^{1} \mathrm{H}$ and ${ }^{13} \mathrm{C}$ chemical shifts are referenced to internal TMS $(\delta$ $\left.{ }^{1} \mathrm{H} 0 \mathrm{ppm}\right)$, and internal $\mathrm{CDCl}_{3}\left(\delta^{13} \mathrm{C} 77.0 \mathrm{ppm}\right)$, respectively.

\section{Western-Blot Analysis and Immunodetection}

In order to detect recombinant proteins in bacterial extracts proteins were expressed with amino-terminal His-Tags. Proteins were separated by SDS-PAGE, transferred from the gel to a nitrocellulose membrane and as primary antiserum an anti-tetra-His (Qiagen) was used.

\section{Phylogenetic analysis}

Phylogenetic tree analysis was performed on deduced amino acid sequences of selected LOXs and NspLOX using phylip 3.5 (Department of Genome Sciences, University of Washington). 


\section{RESULTS}

\section{Isolation of NspLOX Protein and Its Domains}

Database searches and alignments of available LOX amino acid sequences revealed a sequence harbouring two putative enzymatic domains (Acc. no. NP_478445 in the published genome sequence of the cyanobacterium $N$. sp. PCC 7120). The deduced open reading frame was termed NspLOX. The amino acid sequence of NspLOX exhibited an identity of $34 \%$ to an AOS-LOX fusion-protein from the coral Plexaura homomalla (Acc. no. AAC47743) [18]. In addition, amino acid sequence comparisons were performed individually for each portion of the protein, revealing $40 \%$ sequence identity of the amino-terminal domain to a protein with unknown function from O. sativa (Acc. no. XP 472850). With 16\% identity, the LOXactive site domain located at the carboxy-terminal part showed only little similarity to the arachidonate (8R)-LOX domain of the fusion-protein from $P$. homomalla [18].

Phylogenetic analysis of the amino acid sequence of the full-length protein with other known LOX-sequences showed that NspLOX could be grouped with the family of LOXs and was closely related to other sequences identified in prokaryotic organisms (Figure 1). The prokaryotic branch was subdivided into two subgroups, with NspLOX and a hypothetical protein from Myxососсus xanthus forming a separate clade. It is interesting to note that the prokaryotic enzymes are more closely related to LOXs from mammals and coral than to LOXs from plants.

An alignment of the deduced amino acid sequence of the amino-terminal portion revealed high similarity to peroxidase-like sequences from O. sativa, the coral P. homomalla [18] and the bacterium Sulfitobacter sp. EE-36. All sequences share conserved amino acids implicated in forming the active site of a peroxidase, either in heme binding or as catalytic residues. In the AOS domain of the coral fusion-protein, three residues, Thr-66, His-67 and Asn-137, are important for coordinating the distal face of the heme group; the heme's proximal-side 
residues are occupied by Arg 349 and Tyr 353 [18,24]. In the amino-terminal domain of NspLOX the residues that may coordinate the distal face of a heme group are conserved as Thr-40, His-41 and Asn-118. In contrast, the residues on the proximal face of the heme group differ from those of the coral enzyme, and instead of Arg-349 a glycine is situated at the corresponding position (Gly-323), while the position of Tyr-353 corresponds to His-327 with the neighbouring amino acid a tyrosine (Tyr-328).

The alignment of the carboxy-terminal LOX-domain of NspLOX with known LOX sequences showed, that the residues involved in iron binding within the active site (His-170, His-175, His-342 and Asn-346) are highly conserved and identical to those from plant LOXs (Figure 2, marked by stars). However, due to a long carboxy-terminal deletion in the sequence of the LOX domain the fifth ligand did not align properly to the other sequences but was suggested to be represented by an isoleucine (lle-429) as for other plant LOXs (Figure 2, li). At the position of the three determinants that may be involved in regiospecificity NspLOX contains different amino acids in comparison to the other LOX sequences from flowering plants [25-27]. At the site described first by Sloane and co-workers, a serine (Ser-229) is found instead of a phenylalanine in both plant LOXs (LOX2 At2 and PpLOX1; Figure 2, s1). At the position first described by Borngräber and co-workers, a phenylalanine (Phe-163) is found instead of an alanine or isoleucine in both plant LOXs (LOX2 At2 and PpLOX1; Figure 2, bo). These amino acids together differ remarkably from the reported determinants for positional specificity of plant LOXs [26], precluding accurate prediction of positional specificity of the LOX-domain. In addition, an arginine residue reported to determine inverse substrate orientation in plant LOXs is missing as well in NspLOX (Figure 2, ho) [26]. However, the amino acid residue determining the stereospecificity of LOXs (Coffa site, Figure 2, cof) is an alanine residue, suggesting that this enzyme is an S-specific LOX [28].

To isolate the NspLOX protein and its putative domains, gene specific primers were used to amplify the full-length protein and the separate domains from genomic DNA of $N$. sp. PCC 
7120. The DNA-fragment encoding the full-length fusion-protein had a complete open reading frame of $2322 \mathrm{bp}$, encoding a protein of 774 amino acids with a molecular mass of $70.9 \mathrm{kDa}$. The analysis of the three obtained fragments via gel electrophoresis showed, that the amino-terminal domain as well as the full-length protein were about $1300 \mathrm{bp}$ longer than expected from the published genomic sequence of the NspLOX gene. Sequence analysis of the two fragments in question revealed the presence of a large transposon insertion within the region encoding the amino-terminal domain, causing a frame shift. This insertion had highest similarity to the putative transposase gene IS891N, identified in Nostoc ellipsosporum (Acc. no. U48694). The insertion was removed via PCR mutagenesis to allow expression of the intact NspLOX protein. To investigate the catalytical activities of full-length protein and the two separate portions, we made three corresponding constructs, which were overexpressed in E. coli (DE3) expression strains.

\section{The NspLOX Carboxy-terminal Portion Exhibits Activity as a Linoleate (9R)-LOX.}

The activity of the carboxy-terminal portion was tested with free fatty acid substrates and the methyl ester of LA. The enzyme showed activity with all free substrates and converted LA, $\alpha$ linolenic acid (ALA) and $\gamma$-linolenic acid (GLA) predominantly to the corresponding 9hydroperoxides. The corresponding ratios of the different regioisomers formed are shown in Figure 3. AA was mainly converted to 11-hydro(pero)xy-5,8,12,14-eicosatetraenoic acid (11H(P)ETE). With LA methyl ester no activity was detectable. CP-HPLC revealed that the main enantiomer of the hydroxide formed was in $R$ configuration (Figure 3, left inset). Therefore, the carboxy-terminal portion of NspLOX was identified as a linoleate (9R)-LOX, as the analysis of endogenous fatty acids of $N$. sp. showed no C20 fatty acid which could be a potential substrate for the carboxy-terminal portion of NspLOX (Table 1).

The pH-optimum of the LOX-domain was investigated by monitoring the oxygen consumption during substrate conversion. The highest activity of the LOX-domain was 
between $\mathrm{pH} 7.0$ and $\mathrm{pH}$ 10.0, and the activity decreased dramatically above $\mathrm{pH} 10.5$. Furthermore, we aimed to determine the preferred substrates of the LOX domain by incubating the supernatant of E. coli cell lysates with a mixture of LA, ALA, GLA and AA. ALA was the preferred substrate of the LOX-domain (70\% substrate conversion), whereas GLA, AA and LA were converted to a lesser extent of about $54 \%, 46 \%$, and $42 \%$, respectively.

The Amino-terminal Portion of NspLOX Does Not Exhibit Detectable Enzymatic Activity on its Own.

To test whether the amino-terminal portion of NspLOX had enzymatic activity on its own the supernatants of lysates of E. coli cells expressing the fragment were incubated with one product of the LOX-reaction, (9R)-HPODE and as a negative control with (13S)-HPODE. In addition the reduced hydroperoxides (9R)-HODE and (13S)-HODE were tested. With all tested substrates, including $\left[1-{ }^{14} \mathrm{C}\right]-9-\mathrm{HPODE}$, no activity was detectable. However, the protein was formed as verified by Western Blot analysis (data not shown).

\section{Production of Dihydroxylated Fatty Acids by NspLOX.}

Next we aimed at characterizing the activity of the full-length NspLOX protein. NspLOX was tested by incubation with free fatty acids (LA, ALA, GLA and AA) as substrates and subsequent product analysis by reverse phase HPLC, HPLC/MS and GC/MS. HPLC-analysis showed, that conversion of LA resulted in one main product peak and several smaller peaks (Figure 4). Besides the intermediate product of the LOX domain, (9R)-HPODE eluting at about $24 \mathrm{~min}$ and absorbing at $234 \mathrm{~nm}$, all additional newly formed substances were more polar than the monohydroperoxide of the LOX reaction and had absorption maxima at $232 \mathrm{~nm}$ (Figure 4), whereby the peaks eluting later than 24 min were present in the empty vector control as well. By HPLC/MS-analysis the major three products were identified as 
dihydroxide isomers of the fatty acid substrates (Table 2). Additional GC/MS analysis of silylated product derivatives allowed the identification of the positions of the hydroxyl groups and double bonds, and the main product of LA conversion was identified as 9,14-dihydroxy10,12-octadecadienoic acid by GC/MS and LC/MS analysis (9,14-diHODE; Figure 5A, Table 2). The mass spectrum (Figure 5A) was characterized by diagnostic ions at $\mathrm{m} / \mathrm{z} 439$ $\left[M^{+}-31, \text { loss of } \mathrm{OCH}_{3}\right]^{+}, \mathrm{m} / \mathrm{z} 413\left[M^{+}-57 \text {, loss of } \mathrm{CH}_{3}-\left(\mathrm{CH}_{2}\right)_{3}\right]^{+}, \mathrm{m} / \mathrm{z} 380\left[M^{+}-90\right.$; loss of $\left.\mathrm{Me}_{3} \mathrm{SiOH}\right]^{+}, \mathrm{m} / \mathrm{z} 323\left[\mathrm{M}^{+}-147 \text {; loss of } \mathrm{CH}_{3}-\left(\mathrm{CH}_{2}\right)_{3} \text { and } \mathrm{Me}_{3} \mathrm{SiOH}\right]^{+}, \mathrm{m} / \mathrm{z} 259$ [Me $3 \mathrm{SiO}-\mathrm{CH}-$ $\left.\left(\mathrm{CH}_{2}\right)_{7} \mathrm{COO}-\mathrm{CH}_{3}\right]^{+}, \quad \mathrm{m} / \mathrm{z} 223\left[\mathrm{CH}_{3}-\left(\mathrm{CH}_{2}\right)_{2}-\mathrm{CH}=\mathrm{CH}-\mathrm{CH}=\mathrm{CH}-\mathrm{CH}=\mathrm{CH}-\mathrm{CH}=\mathrm{OMe}_{3} \mathrm{SiO}\right]^{+}, \mathrm{m} / \mathrm{z}$ $211\left[\mathrm{CH}_{3}-\left(\mathrm{CH}_{2}\right)_{3}-\mathrm{CH}-\left(\mathrm{OMe}_{3} \mathrm{Si}\right)-\mathrm{CH}=\mathrm{CH}-\mathrm{CH}=\mathrm{CH}\right]^{+}, \mathrm{m} / \mathrm{z} 191$ [intra molecular fragment: $\left.\left(\mathrm{OMe}_{3} \mathrm{Si}\right)_{2}-\mathrm{CH}\right]^{+}, \mathrm{m} / \mathrm{z} 159\left[\mathrm{CH}_{3}-\left(\mathrm{CH}_{2}\right)_{3}-\mathrm{CH}-\left(\mathrm{OMe}{ }_{3} \mathrm{Si}\right)\right]^{+}$and $\mathrm{m} / \mathrm{z} 73\left[\mathrm{Me}_{3} \mathrm{Si}^{+}\right]$. The massspectrometric analysis left the double bond configuration of 9,14-diHODE unresolved. However, from the UV absorption at $232 \mathrm{~nm}$ an E, E configuration was assigned. In addition the double bond configuration of 9,14-diHODE was confirmed via NMR-analysis (Table 3). ${ }^{1} \mathrm{H}$ and ${ }^{13} \mathrm{C}$ chemical shifts are in good agreement with those of $(7 E, 9 E)$-hexadeca-7,9-diene6,11-diol but distinct from those of (7Z,9Z)-hexadeca-7,9-diene-6,11-diol [29]. The two other main products were identified as $(11 E, 13 E)-9,10$-dihydroxy-11,13-octadecadienoic acid (9,10-diHODE) and (9E,12E)-8,11-dihydroxy-9,12-octadecadienoic acid (8,11-diHODE) by mass spectrometry. The corresponding ions in $\mathrm{m} / \mathrm{z}$, ion structure and relative intensities are given in Table 2. Three additional minor products were not identified so far (Figure 4, marked by stars).

For the conversion of ALA, GLA and AA we obtained an equivalent HPLC pattern: one main product and several side products. The main products were $(10 E, 12 E, 14 E)-9,16-$ dihydroxy-10,12,14-octadecatrienoic acid (9,16-diHOTE) for ALA, (6Z,10E,12E)-9,14dihydroxy-6,10,12-octadecatrienoic acid (9,14-diHOTE) for GLA and $(5 Z, 8 Z, 12 E, 14 E)$ 11,16-dihydroxy-5,8,12,14-eicosatetraenoic acid (11,16-diHETE) for AA. The most prominent ions in the mass spectra of 9,16-diHOTE were as follows in $\mathrm{m} / \mathrm{z}$ and ion structure: 
$437\left[M^{+}-31 \text {, loss of } \mathrm{OCH}_{3}\right]^{+}, 378\left[M^{+}-90 \text {; loss of } \mathrm{Me}_{3} \mathrm{SiOH}\right]^{+}, 337\left[M^{+}-131\right.$, loss of $\mathrm{CH}_{3}-\mathrm{CH}_{2}-$ $\left.\mathrm{CH}-\left(\mathrm{OMe}_{3} \mathrm{Si}\right)\right]^{+}, \quad 259 \quad\left[\mathrm{Me}_{3} \mathrm{SiO}-\mathrm{CH}-\left(\mathrm{CH}_{2}\right)_{7} \mathrm{COO}-\mathrm{CH}_{3}\right]^{+}, \quad 209 \quad\left[\mathrm{CH}_{3}-\mathrm{CH}_{2}-\mathrm{CH}-\left(\mathrm{OMe}{ }_{3} \mathrm{Si}\right)-\right.$ $\mathrm{CH}=\mathrm{CH}-\mathrm{CH}=\mathrm{CH}-\mathrm{CH}=\mathrm{CH}]^{+}, 191$ intra molecular fragment: $\left.\left(\mathrm{OMe}_{3} \mathrm{Si}\right)_{2-} \mathrm{CH}\right]^{+}, 131\left[\mathrm{CH}_{3}-\mathrm{CH}_{2-}\right.$ $\left.\mathrm{CH}-\left(\mathrm{OSiMe}_{3}\right)\right]^{+}$. For 9,14-diHOTE the following ions in $\mathrm{m} / \mathrm{z}$ and ion structure could be found: $313\left[M^{+}-155 \text {, loss of } \mathrm{CH}_{2}-\mathrm{CH}=\mathrm{CH}-\left(\mathrm{CH}_{2}\right)_{4}-\mathrm{COOCH}_{3}\right]^{+}, 256\left[\mathrm{Me}_{3} \mathrm{SiO}-\mathrm{CH}-\mathrm{CH}=\mathrm{CH}-\mathrm{CH}=\mathrm{CH}-\right.$ $\left.\mathrm{CH}-\mathrm{OSiMe}_{3}\right]^{+}, \quad 223\left[\mathrm{CH}_{3}-\left(\mathrm{CH}_{2}\right)_{2}-\mathrm{CH}=\mathrm{CH}-\mathrm{CH}=\mathrm{CH}-\mathrm{CH}=\mathrm{CH}-\mathrm{CH}=\mathrm{OMe}_{3} \mathrm{SiO}\right]^{+}, \quad 191 \quad$ intra molecular fragment: $\left.\left(\mathrm{OSiMe}_{3}\right)_{2} \mathrm{CH}\right]^{+}$and $159\left[\mathrm{CH}_{3}-\left(\mathrm{CH}_{2}\right)_{3}-\mathrm{CH}-\left(\mathrm{OSiMe}_{3}\right)\right]^{+}$. The most prominent ions in the mass spectra of 11,16-diHETE were as follows in $\mathrm{m} / \mathrm{z}$ and ion structure: $313\left[\mathrm{Me}_{3} \mathrm{SiO}-\mathrm{CH}-\mathrm{CH}=\mathrm{CH}-\mathrm{CH}=\mathrm{CH}-\mathrm{CH}-\left(\mathrm{OMe}_{3} \mathrm{Si}\right)-\left(\mathrm{CH}_{2}\right)_{3}-\mathrm{CH}_{3}\right]^{+}, \quad 283 \quad\left[\mathrm{Me}_{3} \mathrm{SiO}-\mathrm{CH}-\mathrm{CH}_{2}-\right.$ $\left.\mathrm{CH}=\mathrm{CH}-\mathrm{CH}_{2}-\mathrm{CH}=\mathrm{CH}-\left(\mathrm{CH}_{2}\right)_{3}-\mathrm{COOCH}_{3}\right]^{+}, \quad 256 \quad\left[\mathrm{Me}_{3} \mathrm{SiO}-\mathrm{CH}-\mathrm{CH}=\mathrm{CH}-\mathrm{CH}=\mathrm{CH}-\mathrm{CH}-\right.$ $\mathrm{OMe}_{3} \mathrm{Si}^{+}, \quad 211\left[\mathrm{CH}_{3}-\left(\mathrm{CH}_{2}\right)_{3}-\mathrm{CH}-\left(\mathrm{OMe} \mathrm{Si}_{3}\right) \mathrm{CH}=\mathrm{CH}-\mathrm{CH}=\mathrm{CH}\right]^{+}, \quad 191$ [intra molecular fragment: $\left.\left(\mathrm{OMe}_{3} \mathrm{Si}\right)_{2} \mathrm{CH}\right]^{+}, 159\left[\mathrm{CH}_{3}-\left(\mathrm{CH}_{2}\right)_{3}-\mathrm{CH}-\left(\mathrm{OMe}_{3} \mathrm{Si}\right)\right]^{+}$.

Several trapping experiments were performed, but no allene oxides were detected. The formation of dihydroxy fatty acids started immediately after addition of either LA or ALA to the reaction mix. (9R)-HPO(D/T)E and dihydroxides were detectable as early as $20 \mathrm{~s}$ after substrate addition, with 9,14-diHO(D/T)E being the major product. Furthermore, the intermediate $(9 R)-\mathrm{HPO}(\mathrm{D} / \mathrm{T}) \mathrm{E}$ was present over the whole time course of $120 \mathrm{~min}$, at approximately constant amounts. The pH-optimum of NspLOX was similar to that of the LOX domain alone, the highest activity being observed in the $\mathrm{pH}$ range between 7 and 10.5 .

Since the carboxy-terminal portion was identified as a (9R)-LOX, we anticipated that the oxygen at C-9 derives from dioxygen. To investigate the origin of the second oxygen at C-14, we performed activity tests in the presence of either ${ }^{18} \mathrm{O}_{2}$ or $\mathrm{H}_{2}{ }^{18} \mathrm{O}$. Reaction products were analyzed by GC/MS and LC/MS, allowing for the unequivocal identification of diagnostic mass fragments. The mass spectra of 9,14-diHODE for the experiment with ${ }^{18} \mathrm{O}_{2}$ revealed that only the first oxygen atom derived from ${ }^{18} \mathrm{O}_{2}$, whereas the second oxygen atom remained unlabelled (Figure 5B, ${ }^{18} \mathrm{O}$-containing fragments are marked by stars). The fragments 
containing the C-9 atom with the first hydroxy group, deriving from the LOX reaction, contained the labelled oxygen atom: $m / z$ 472, $m / z 441\left[M^{+}-31 \text {, loss of } \mathrm{OCH}_{3}\right]^{+}, \mathrm{m} / \mathrm{z} 415\left[\mathrm{M}^{+}-\right.$ 57, loss of $\left.\mathrm{CH}_{3}-\left(\mathrm{CH}_{2}\right)_{3}\right]^{+}, \mathrm{m} / \mathrm{z} 382\left[\mathrm{M}^{+}-90 \text {; loss of } \mathrm{Me}_{3} \mathrm{SiOH} \text { at C-9 }\right]^{+}, \mathrm{m} / \mathrm{z} 261\left(\mathrm{Me}_{3} \mathrm{Si}\left[{ }^{18} \mathrm{O}\right]-\right.$ $\left.\mathrm{CH}-\left(\mathrm{CH}_{2}\right)_{7} \mathrm{COO}-\mathrm{CH}_{3}\right]^{+} \quad$ and $\quad \mathrm{m} / \mathrm{z} \quad 225 \quad\left[\mathrm{CH}_{3}-\left(\mathrm{CH}_{2}\right)_{2}-\mathrm{CH}=\mathrm{CH}-\mathrm{CH}=\mathrm{CH}-\mathrm{CH}=\mathrm{CH}-\right.$ $\left.\mathrm{CH}=\left[{ }^{18} \mathrm{O}\right] \mathrm{SiMe}_{3}\right]^{+}$. In contrast, the obtained mass fragments of 9,14-diHODE containing the second hydroxy group at C-14 were only labelled, when LA was converted in the presence of $\mathrm{H}_{2}{ }^{18} \mathrm{O}$ (Figure $5 \mathrm{C},{ }^{18} \mathrm{O}$-containing fragments are marked by stars). The mass spectra showed mass ions at $m / z$ 441 $\left(M^{+}-31\right.$, loss of $\left.\mathrm{OCH}_{3}\right), \mathrm{m} / \mathrm{z} 325\left[\mathrm{M}^{+}-147\right.$; loss of $\mathrm{Me}_{3} \mathrm{SiOH}$ from C-9 and $\left.\mathrm{CH}_{3}-\left(\mathrm{CH}_{2}\right)_{3}\right]^{+}$and $\mathrm{m} / \mathrm{z} 161\left(\mathrm{CH}_{3}-\left(\mathrm{CH}_{2}\right)_{3}-\mathrm{CH}-\left(\left[{ }^{18} \mathrm{O}\right] \mathrm{Me}_{3} \mathrm{Si}\right)\right]^{+}$.

Thus, the NspLOX seemed to catalyze the conversion of the fatty acid substrate in a two step reaction: First the carboxy-terminal portion (LOX domain) converted LA to $(9 R)$ HPODE in a reaction depending on molecular oxygen. In a second step, (9R)-HPODE or an unstable metabolite that derived there from was metabolized to $(10 E, 12 E)-9,14$-diHODE by the full-length protein in a reaction introducing an oxygen atom not derived from the peroxy group of (9R)-HPODE but from water.

\section{Analysis of Endogenous Oxylipins in N. sp. PCC 7120.}

So far, we have described the in vitro characterization of NspLOX isolated from the $N$. sp. strain PCC 7120. Analysis of the isolated sequences showed, that it harbours an insertion in form of a transposon in the NspLOX sequence. In order to compare the dependency of cyanobacterial oxylipin formation on the NspLOX protein, two additional $N$. sp. strains, PCC 7120 A and P collectively named wildtype (wt) strains, were obtained, which do not harbour a disruptive insertion in the NspLOX-gene. The three strains showed the same growth behaviour and analysis of lipid as well as fatty acid patterns revealed that there were no obvious differences between cells containing a functional and dysfunctional gene for NspLOX. 
Considering that the insertion in the NspLOX gene presumably results in the translation of an inactive NspLOX enzyme, oxylipin metabolism of the cyanobacterial strains harbouring the insertion in NspLOX may be compromised. The potential differences in oxylipin metabolism were exploited to compare the "wildtype-allele" (wt) strains PCC $7120 \mathrm{~A}$ and P with the "mutant-allele" (mt) strain PCC 7120 with respect to their oxylipin profiles. As it is known from previous work that the LOX-pathway is induced upon ultrasonification in algae and mosses [11,30-32], cyanobacterial cultures were subjected to ultrasonification, and the effects on oxylipin metabolism were monitored.

In all samples free hydro(pero)xy dienoic fatty acids were measured. Although we detected C16- and C18-derived PUFAs in wt and mt-strains (Table 1), only C18-PUFAderived hydroxides were detected in untreated and treated cells, and no C16-PUFA-derived oxylipins were present. In addition, traces of fatty acid hydroperoxides were detected. The analysis of free oxylipins in the wt strains showed, that the most abundant hydroxy fatty acids were 9-HODE and 9-HOTE that derived from 9-LOX activity, since both substances showed a clear preponderance of the $R$-enantiomer $(0.3-1.0 \mathrm{nmol} / \mathrm{g}$ f.w.; Figure $6 \mathrm{~A}$, grey bars, shown for PCC 7120 P; inset shows the CP-HPLC analysis of 9-HODE). The amount of the hydroxy fatty acids increased upon sonification, in particular that of 9-hydroxy fatty acids, which showed an almost ten-fold increase (9.1-11.7 nmol/g f.w., Figure 6A, grey vs. black bars). The amount of the other hydroxy fatty acids (13-HODE, 13HOTE, 12-HOTE and 16-HOTE) increased only slightly to about $0.8 \mathrm{nmol} / \mathrm{g}$ f.w.. In comparison, the mt strain contained similar amounts of hydroxy fatty acids between 0.1 and $0.5 \mathrm{nmol} / \mathrm{g}$ f.w. (Figure $6 \mathrm{~B}$ ), and there was only a slight preference for the 9-hydroxy fatty acid isomers. In addition, only a threefold induction of oxylipin formation was observed upon sonification with no preference for a hydroxy fatty acid isomer (Figure 6B). These data indicated an induction of (9R)-LOX activity in the wt strains upon sonification and the absence of LOX activity in the mt strain, most likely due to the insertion of a disruptive transposase insert into the NspLOX-gene. 
Interestingly, neither in wt nor in mt strains any dihydroxylated fatty acids products of NspLOX were detected under the conditions used, contrasting with the results from the in vitro tests with the recombinant enzyme.

Since we failed to detect any dihydroxy fatty acids that may derive from the activity of NspLOX we aimed to measure extractable enzyme activity that may derive from NspLOX. Therefore we analyzed cell extracts obtained from sonified and non sonified mt and wt strains either after incubation with LA or $\left[1-{ }^{14} \mathrm{C}\right]$-labelled LA. In the untreated samples, formation of neither monohydroxylated nor dihydroxylated fatty acids was detected. However, stressinduced formation of $(9 R)$-HODE was found in wt strains. Again, neither formation of 9,14diHODE nor that of any other dihydroxy fatty acid was detected. The results for the two wt strains were similar, whereas for the mt-strain no oxylipins were found.

\section{DISCUSSION}

The NspLOX protein identified in the present study is a candidate for a cyanobacterial enzyme generating (9R)-LOX products with a possible function in stress responses of cyanobacteria. Lipidperoxidation in the better-characterized flowering plants is mainly a controlled process catalyzed by enzymes of the LOX enzyme family [5], and products originating from the LOX reaction can be further metabolized in the LOX pathway. Plant products of the LOX-pathway have demonstrated roles as signalling substances in plant development or during plant responses to wounding or pathogen attack [33,34].

The data presented here support the presence of enzymatic oxylipin production in prokaryotes, which suggests an early advent of oxylipin signalling in evolution, however, clear differences to plant oxylipin metabolism are also obvious. While LOXs can be ubiquitously found among higher plant species, our analysis shows that yet only two 
cyanobacterial genomes harbour putative open reading frames that may encode for LOXs (Figure 1). N. punctiforme strain PCC 73102 was first analyzed as the most promising candidate, since its genome harbours two genes encoding different LOX enzymes being more related to plant LOXs than the third one PCC 7120, which is described in this report. Recently, the first two candidates were positively identified as linoleate 13-LOXs [10,11] and it is tempting to assume that these enzymes may resemble the evolutionary precursors of plastidial 13-LOXs found in plants [5].

In this study we analyzed a third candidate representing a LOX protein with a large amino-terminal extension from the cyanobacterium $N$. sp. PCC 7120, termed NspLOX. Amino acid sequence comparisons indicate substantial similarity between NspLOX and the AOS-LOX fusion-protein from the coral P. homomalla [18]. The coral enzyme converts AA to $(8 R)$-HPETE by its LOX domain, which is then further metabolized by the peroxidase domain of the same protein to an unstable allene oxide which immediately hydrolyzes to the corresponding $\alpha$-ketols [18]. Despite of a comparable protein domain structure we could not detect fatty acid-derived ketols as products of NspLOX, and observed instead formation of fatty acid dihydroxides (Figs. 4 and 5).

Diagnostic differences or similarities within the structure of a LOX are mainly found around the active site residues of the protein $[5,14]$. The iron binding site of plant LOXs is formed by a central histidine-rich region that is conserved in NspLOX [35], with the exception of a long carboxy-terminal deletion in its sequence. Due to the deletion the fifth ligand does not align properly to the other sequences, but is most likely represented by Ile-429 as in other plant LOXs (Figure 2). Since structural modelling is not possible due to low sequence similarities to the available data sets of LOX1 and LOX3 from soybean [36,37] and the rabbit reticulocyte $15-\mathrm{LOX}$ [38], it remains open whether Ile-429 has access to the active site of the LOX. Additional determinants conserved in evolution between NspLOX and other LOXs from plants and mammals [25-27] have been found to be involved in the substrate- and 
regiospecificity of LOXs. The amino acid residues determining the stereospecificity of all LOXs characterized so far (Coffa site) suggested for the NspLOX to be an S-specific LOX [28]. In contrast to this prediction, we were able to demonstrate that NspLOX acts as a (9R)LOX (Figure 3 and 6), to our knowledge representing the first LOX deviating in specificity from that indicated by the Coffa site. Thus, our results indicate that either more than one amino acid residue in the active site may be involved in determining the stereospecificity of LOXs or that in this case an amino acid with a larger side chain would lead to (9S)-LOX activity. Moreover, our analysis on substrate specificity of NspLOX indicates that the fusionprotein "counts" from the methyl end of the substrate to insert the first oxygen molecule.

In addition to the carboxy-terminal LOX domain the NspLOX protein contained an amino-terminal extension with similarity to peroxidase enzymes and especially resembling catalases. Catalases are specialized peroxidases that metabolize hydrogen peroxide. Indications to possible functions of the amino-terminal part come from the investigation of the related coral AOS-LOX fusion-protein from the coral P. homomalla [18]. In the peroxidase domain of NspLOX a number of highly conserved residues at the distal face of the heme group are characteristic for peroxidases (Thr-40, His-41 and Asn-118) and may be related to enzymatic function although we failed to show the amino-terminal part of the enzyme is active on its own.

NspLOX is localized on the Gamma plasmid of the bacterium and, thus, it is tempting to assume that it was taken up by horizontal gene transfer from other bacteria. The similar gene structure of PhAOS-LOX and NspLOX and the notion, that many corals either live in symbiosis with algae so called zooxanthellae or are parasited by cyanobacteria may suggest a common algal origin of such enzymes. However, since only a restricted search in published genomes of bacteria and microalgae is currently possible, considerations about their origin must remain speculative at this point. However, the positive analysis of endogenous oxylipins detected in N. sp. PCC 7120 may give first hints for a potential physiological function of 
NspLOX in this cyanobacterium. Analysis of oxylipin profiles in N. sp. PCC 7120 indicates that this organism may primarily form oxylipins that derive from the $(9 R)$-LOX activity of NspLOX at least under conditions used in this study. So far nothing is known about the function of 9-LOX-derived hydro(pero)xy C18-PUFAs in cyanobacteria, a class of compounds recently discussed to be involved in triggering cell death in pathogen-infected plant cells [39-41] and possibly involved in the regulation of root development [42].

Surprisingly, neither the products derived from the linoleate diol synthase activity of NspLOX nor those of additional enzymes metabolizing the 9-LOX-derived fatty acid hydroperoxides, as known from the so-called LOX pathway in higher plants, were found so far (Figure 6) and, thus, such enzymes seem to be absent from N. sp. PCC 7120. Besides the gene encoding NspLOX, no other open reading frames were found in the genome of $N$. sp. PCC 7120 that may encode additional LOXs or other enzymes of the LOX pathway as it is known from higher plants. It should be noted that the appearance of (9R)-HOTE/HODE is not unusual in cyanobacteria of the genus Anabaena, as has been reported before [17], and that (9R)-HOTE/HODE has been shown to occur in the eukaryotic alga, Ulva conglobata [43], while dihydroxy fatty acids similar in structure to those formed in vitro by NspLOX have been described to occur in red algae [44].

Based on the biochemical data and phylogenetic relationships among enzymes studied so far, it appears that in evolution the use of bi- or multifunctional enzymes may represent a more ancient way to form and to control the intracellular amount of oxylipins, whereas metabolic pathways involved in the formation of more complex oxylipins, such as jasmonates or green leaf-volatiles, may have emerged at a later stage during evolution together with the rise of more complex and multicellular organisms. 


\section{ACKNOWLEDGEMENTS}

The authors are grateful to Dr. Fredi Brühlmann, Geneva, Dr. Maike Lorenz, Goettingen, and Prof. Thomas Friedl, Goettingen, for continuous support and stimulating discussions, to Prof. Peter Wolk, East Lansing, MI, USA and Prof. James Golden, College Station, TX, USA for providing us with additional strains of PCC 7120, Prof. Klaus Raschke, Goettingen, for providing us with $\mathrm{H}_{2}{ }^{18} \mathrm{O}$, to Dr. Michael Stumpe, Goettingen, who prepared radio-labeled [1${ }^{14}$ C]-(9S)-HPODE, and to Dr. Juergen Schmidt, Halle/Saale, for his help with the identification of mass fragments. Sequence data from this article can be found in the GenBank/EMBL data libraries under accession number NP_478445. This work was supported by Firmenich SA (Geneva, Switzerland).

\section{REFERENCES}

1 Potin, P., Bouarab, K., Salaün, J.-P., Pohnert, G. and Kloareg, B. (2002) Biotic interactions of marine algae. Curr. Opin. Plant Biol. 5, 308-17

2 Pohnert, G. (2005) Diatom/copepod interactions in plankton: The indirect chemical defense of unicellular algae. ChemBioChem 6, 1-14

3 Blée, E. (2002) Impact of phyto-oxylipins in plant defense. Trends Plant Sci. 7, 315322

4 Hamberg, M. and Gardner, H. W. (1992) Oxylipin pathway to jasmonates: biochemistry and biological significance. Biochim. Biophys. Acta 1165, 1-18

5 Liavonchanka, A. and Feussner, I. (2006) Lipoxygenases: Occurrence, functions and catalysis. J. Plant Physiol. 163, 348-357

6 Brash, A. R. (1999) Lipoxygenases: Occurrence, functions, catalysis, and acquisition of substrate. J. Biol. Chem. 274, 23679-23682 
7 Feussner, I. and Wasternack, C. (2002) The lipoxygenase pathway. Annu. Rev. Plant Biol. 53, 275-297

8 Kühn, H. and Thiele, B. J. (1999) The diversity of the lipoxygenase family - Many sequence data but little information on biological significance. FEBS Lett. 449, 7-11

9 Brash, A. R., Boeglin, W. E., Chang, M. S. and Shieh, B.-H. (1996) Purification and molecular cloning of an 8R-lipoxygenase from the coral Plexaura homomalla reveal the related primary structures of $R$ - and $S$-lipoxygenases. J. Biol. Chem. 271, 2094920957

10 Koeduka, T., Kajiwara, T. and Matsui, K. (2007) Cloning of lipoxygenase genes from a cyanobacterium, Nostoc punctiforme, and its expression in Eschelichia coli. Curr. Microbiol. 54, 315-319

11 Lang, I. and Feussner, I. (2007) Oxylipin formation in Nostoc punctiforme (PCC73102). Phytochemistry 68, 1120-1127

12 Senger, T., Wichard, T., Kunze, S., Göbel, C., Lerchl, J., Pohnert, G. and Feussner, I. (2005) A multifunctional lipoxygenase with fatty acid hydroperoxide cleaving activity from the moss Physcomitrella patens. J. Biol. Chem. 280, 7588-7596

13 Vidal-Mas, J., Busquets, M. and Manresa, A. (2005) Cloning and expression of a lipoxygenase from Pseudomonas aeruginosa 42A2. Antonie van Leeuwenhoek 87, $245-251$

14 Kühn, H., Saam, J., Eibach, S., Holzhütter, H.-G., Ivanov, I. and Walther, M. (2005) Structural biology of mammalian lipoxygenases: Enzymatic consequences of targeted alterations of the protein structure. Biochem. Biophys. Res. Commun. 338, 93-101

15 Boeglin, W. E., Kim, R. B. and Brash, A. R. (1998) A 12R-lipoxygenase in human skin: Mechanistic evidence, molecular cloning, and expression. Proc. Natl. Acad. Sci. USA 95, 6744-6749 
16 Schneider, C., Keeney, D. S., Boeglin, W. E. and Brash, A. R. (2001) Detection and cellular localization of 12R-lipoxygenase in human tonsils. Arch. Biochem. Biophys. 386, 268-74

17 Murakami, N., Shirahshi, A. N. and Sakakibara, J. (1992) Two unsaturated 9Rhydroxy fatty acids from the cyanobacterium Anabaena flos-aquae $f$. flos-aquae. Lipids 27, 776-778

18 Koljak, R., Boutaud, O., Shieh, B. H., Samel, N. and Brash, A. R. (1997) Identification of a naturally occurring peroxidase-lipoxygenase fusion protein. Science 277, 1994-1996

19 Boutaud, O. and Brash, A. R. (1999) Purification and catalytic activities of the two domains of the allene oxide synthase-lipoxygenase fusion protein of the coral Plexaura homomalla. J. Biol. Chem. 274, 33764-33770

20 Bertani, G. (1951) Studies on lysogenesis. I. The mode of phage liberation by lysogenic Escherichia coli. J. Bacteriol. 62, 293-300

21 Bligh, E. G. and Dyer, W. J. (1959) A rapid method of total lipid extraction and purification. Can. J. Biochem. Physiol. 37, 911-917

22 Hughes, R. K., Belfield, E. J., Ashton, R., Fairhurst, S. A., Göbel, C., Stumpe, M., Feussner, I. and Casey, R. (2006) Allene oxide synthase from Arabidopsis thaliana (CYP74A1) exhibits dual specificity that is regulated by monomer-micelle association. FEBS Lett. 580, 4188-4194

23 Hoffmann, M., Hornung, E., Busch, S., Kassner, N., Ternes, P., Braus, G. H. and Feussner, I. (2007) A small membrane-peripheral region close to the active center determines regioselectivity of membrane-bound fatty acid desaturases from Aspergillus nidulans. J. Biol. Chem. 282, 26666-26674 
24 Oldham, M. L., Brash, A. R. and Newcomer, M. E. (2005) The structure of coral allene oxide synthase reveals a catalase adapted for metabolism of a fatty acid hydroperoxide. Proc. Natl. Acad. Sci. USA 102, 297-302

25 Sloane, D. L., Leung, R., Craik, C. S. and Sigal, E. (1991) A primary determinant for lipoxygenase positional specificity. Nature 354, 149-152

26 Hornung, E., Walther, M., Kühn, H. and Feussner, I. (1999) Conversion of cucumber linoleate 13-lipoxygenase to a 9-lipoxygenating species by site-directed mutagenesis. Proc. Natl. Acad. Sci. USA 96, 4192-4197

27 Borngräber, S., Kuban, R. J., Anton, M. and Kühn, H. (1996) Phenylalanine 353 is a primary determinant for the positional specificity of mammalian 15-lipoxygenases. J. Mol. Biol. 264, 1145-1153

28 Coffa, G. and Brash, A. R. (2004) A single active site residue directs oxygenation stereospecificity in lipoxygenases: Stereocontrol is linked to the position of oxygenation. Proc. Natl. Acad. Sci. USA 101, 15579-15584

29 Tolstikov, G. A., Miftakhov, M. S., Danilova, N. A., Vel'der, Y. L. and Spirikhin, L. V. (1989) A convenient synthesis of symmetrically functionalized 1,3-dienes by palladium(II)-catalyzed homocoupling of 1-alkenylstannanes. Synthesis 8, 633-634

30 Pohnert, G. (2002) Phospholipase $\mathrm{A}_{2}$ activity triggers the wound-activated chemical defense in the diatom Thalassiosira rotula. Plant Physiol. 129, 103-11

31 Wichard, T., Göbel, C., Feussner, I. and Pohnert, G. (2005) Unprecedented lipoxygenase/hydroperoxide lyase pathways in the moss Physcomitrella patens. Angew. Chem. Int. Ed. Engl. 44, 158-161

32 Stumpe, M., Bode, J., Gobel, C., Wichard, T., Schaaf, A., Frank, W., Frank, M., Reski, R., Pohnert, G. and Feussner, I. (2006) Biosynthesis of C9-aldehydes in the moss Physcomitrella patens. Biochim. Biophys. Acta 1761, 301-312 
33 Schilmiller, A. L. and Howe, G. A. (2005) Systemic signaling in the wound response. Curr. Opin. Plant Biol. 8, 369-377

34 Wasternack, C. (2007) Jasmonates: An update on biosynthesis, signal transduction and action in plant stress response, growth and development. Ann. Bot. 100, 681-697

35 Siedow, J. N. (1991) Plant lipoxygenase - structure and function. Ann. Rev. Plant Physiol. Plant Mol. Biol. 42, 145-188

36 Boyington, J. C., Gaffney, B. J. and Amzel, L. M. (1993) The three-dimensional structure of an arachidonic acid 15-lipoxygenase. Science 260, 1482-1486

37 Skrzypczak-Jankun, E., Amzel, L. M., Kroa, B. A. and Funk, M. O. (1997) Structure of soybean lipoxygenase L3 and a comparison with its L1 isoenzyme. Proteins Structure Function and Genetics 29, 15-31

38 Gillmor, S. A., Villasenor, A., Fletterick, R., Sigal, E. and Browner, M. F. (1998) The structure of mammalian 15-lipoxygenase reveals similarity to the lipases and the determinants of substrate specificity. Nat. Struct. Biol. 4, 1003-1009

39 Jalloul, A., Montillet, J. L., Assigbetsé, K., Agnel, J. P., Delannoy, E., Triantaphylidès, C., Daniel, J. F., Marmey, P., Geiger, J. P. and Nicole, M. (2002) Lipid peroxidation in cotton: Xanthomonas interactions and the role of lipoxygenases during the hypersensitive reaction. Plant J. 32, 1-12

40 Montillet, J.-L., Chamnongpol, S., Rusterucci, C., Dat, J., van de Cotte, B., Agnel, J.P., Battesti, C., Inze, D., Van Breusegem, F. and Triantaphylides, C. (2005) Fatty acid hydroperoxides and $\mathrm{H}_{2} \mathrm{O}_{2}$ in the execution of hypersensitive cell death in Tobacco leaves. Plant Physiol. 138, 1516-1526

41 Göbel, C., Feussner, I. and Rosahl, S. (2003) Lipid peroxidation during the hypersensitive response in potato in the absence of 9-lipoxygenases. J. Biol. Chem. 278, 52834-52840 
42 Vellosillo, T., Martinez, M., Lopez, M. A., Vicente, J., Cascon, T., Dolan, L., Hamberg, M. and Castresana, C. (2007) Oxylipins produced by the 9-Lipoxygenase pathway in Arabidopsis regulate lateral root development and defense responses through a specific signaling cascade. Plant Cell 19, 831-846

43 Akakabe, Y., Matsui, K. and Kajiwara, T. (2002) Enantioselective formation of (R)-9HPODE and (R)-9-HPOTrE in marine green alga Ulva conglobata. Bioorg. Med. Chem. 10, 3171-3

44 Hamberg, M. and Gerwick, W. H. (1993) Biosynthesis of vicinal dihydroxy fatty acids in the red alga Gracilariopsis-lemaneiformis - identification of a sodium-dependent 12-lipoxygenase and a hydroperoxide isomerase. Arch. Biochem. Biophys. 305, 115122 
Table 1 Fatty acid composition of $\mathbf{N}$. sp. SAG 25.82. The lipids were extracted from lyophilized cells, esterified fatty acids were transmethylated and GC/FID analysis of fatty acid methyl esters isolated from the cultures was performed as described under materials and methods. All fatty acids were characterized by co-elution of authentic standards. Amount of each fatty acid was expressed as relative ratio of all esterified fatty acids.

\begin{tabular}{|l|l|}
\hline Fatty acid & \% Fatty acid of total fatty acids \\
\hline $16: 0$ & 19.5 \\
\hline $16: 1(9 Z)$ & 21.5 \\
\hline $16: 3(4 Z, 7 Z, 10 Z)$ & 2.2 \\
\hline $18: 1(9 Z)$ & 7.8 \\
\hline $18: 1(11 Z)$ & 4.4 \\
\hline $18: 2(9 Z, 12 Z)$ & 14.0 \\
\hline $18: 3(9 Z, 12 Z, 15 Z)$ & 30.6 \\
\hline
\end{tabular}


Table 2 Overview of the dihydroxy fatty acids formed in the reaction of the NspLOX protein wit $\stackrel{\mathrm{N}}{\mathrm{m}}$ analysis of products was done with HPLC, HPLC/MS and GC/MS. For each substance the absorption maxi⿳⺈⿴囗十灬um [nm] and fragment sizes [m/z] are given. In case of GC/MS spectra the relative intensities of the fragments are given in brackets.

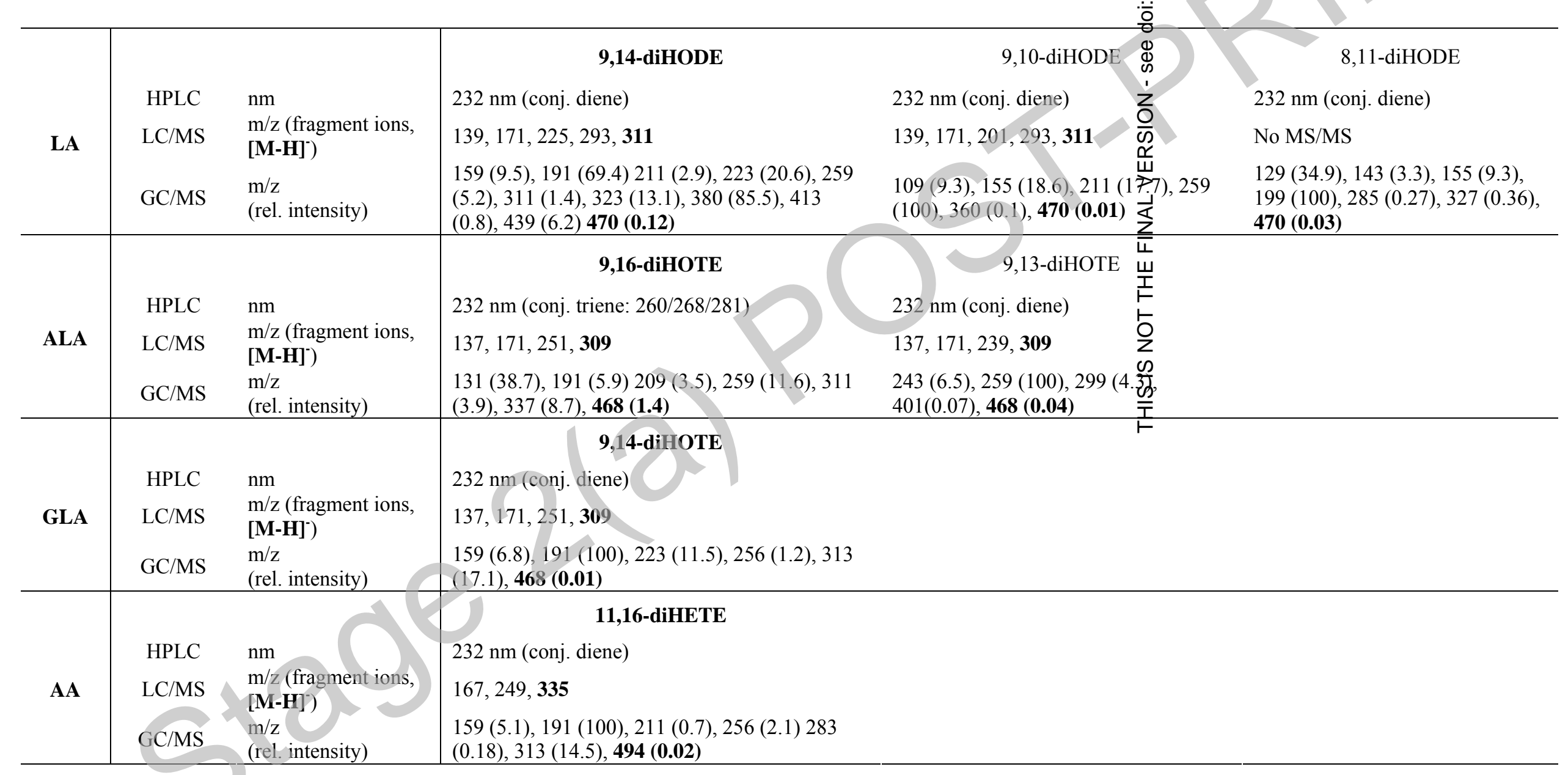


Table 3 Selected NMR data for 9,14-diHODE.

\begin{tabular}{ccc}
\hline $\mathrm{H}$ & $\delta^{1} \mathrm{H}[\mathrm{ppm}]$ & $\delta^{13} \mathrm{C}[\mathrm{ppm}]^{\mathrm{b}}$ \\
\hline 8,15 & $1.54^{\mathrm{a}}$ & n.d. \\
9,14 & 4.15 & 72.7 \\
10,13 & 5.70 & 136.4 \\
11,12 & 6.20 & 129.8
\end{tabular}

$\overline{{ }^{a}} \quad{ }^{1}$-chemical shifts of ${ }^{1} \mathrm{H},{ }^{1} \mathrm{H}$ COSY $2 \mathrm{D} \mathrm{NMR}$ correlation peaks

${ }^{\text {b }}{ }^{13} \mathrm{C}$-chemical shifts of ${ }^{1} \mathrm{H},{ }^{13} \mathrm{C}$ HSQC $2 \mathrm{D}$ NMR correlation peaks

n.d. not detected because of poor signal/noise ratio 


\section{FIGURE LEGENDS}

Figure 1 Phylogenetic analysis of the NspLOX amino acid sequence and selected LOXs from mammals, plants, corals, algae and bacteria, using phylip 3.5. Acc. numbers: Mus musculus: 5-LOX AAC37673; 8-LOX CAA75003; 12RLOX CAA74714; 112-LOX AAA20658; p12LOX AAA20659; e12LOX NP663717; Plexaura homomalla PhAOS-LOX O16025; Arabidopsis thaliana type 2 LOX: LOX2 At1 Q06327; LOX2 At2 CAB56692; LOX2 At3 CAC19364; LOX2 At4 CAG38328; Physcomitrella patens: CAE47464; Solanum tuberosum: St1 CAA5572; St2 AAD09202; St3 AAB31252 ; St4 CAA64766; St5 CAA64765; St6 AAB67860; A. thaliana type1 9-LOX: LOX1 At1 NP175900, LOX1 At2 NP188879, Lycopersicon esculentum Le1 P38415; Nicotiana tabacum Nt1 CAA58859; Glycine max: Gm1 CAA47717; Gm2 P09439; Gm3 CAA31664; Gm4 P38417; Gm5 AAB67732; Gm6 AAA96817; Gm7 AAC49159; Pisum sativum: Ps1 AAB71759; Ps2 CAA55318; Lens culinaris Lc1 CAA50483; Porphyra purpureum: Ppu AAA61791; Pseudomonas aeruginosa: AF479686; Nitrosomonas europaea : BX321860; Shewanella denitrificans OS-217:Q3P217; Photobacterium profundum 3TCK: ZP_01218321, Myxococcus xanthus DK 1622 hypothetical protein MXAN_1745 YP_629995; Nostoc punctiforme (PCC73102): NpLOX1 ZP_00106490; NPLOX2 ZP_00107030, Nostoc sp. SAG 25.82: NspLOX NP_478445.

Figure 2 Partial amino acid sequence alignment of LOX-active site of the NspLOX protein. Comparison with LOX2 At2 (AtLOX3, Acc. no. AAF79461) from Arabidopsis thaliana, PpLOX1 (Acc. No. CAE47464) from Physcomitrella patens, AOS-LOX fusionprotein (PhAOS-LOX, Acc. No. AAC47743) from Plexaura homomalla. Stars: the residues involved in iron ligation (three histidines, an asparagine and an isoleucine; li [35]), and the 
three determinants for substrate and regiospecificity (bo, according to [27], sl, according to [25], ho, according to [26]).

Figure 3 Conversion of LA, ALA and AA by the carboxy-terminal part of NspLOX. The recombinant carboxy-terminal part of NspLOX was incubated with various fatty acid substrates, and the reaction products were analyzed by HPLC. SP- and CP-HPLC: conversion of LA, ALA and AA with the recombinant protein. Amounts of the hydro(pero)xy-fatty acids are given in relative percentage. Products of LA ((9R)-H(P)ODE and (13S)-H(P)ODE), ALA $((9 R)-\mathrm{H}(\mathrm{P}) \mathrm{OTE}$ and $(13 S)-\mathrm{H}(\mathrm{P}) \mathrm{OTE})$ and AA $((15 S)-\mathrm{H}(\mathrm{P}) \mathrm{ETE}$ and $(11 R)-\mathrm{H}(\mathrm{P}) \mathrm{ETE})$ are shown in black bars. Insets show representative CP-chromatograms of (9R)-H(P)ODE and (13S)-H(P)OTE. Each value represents an average of three independent analyses, standard deviation is given.

Figure 4 Product profile of NspLOX conversion of LA. The reaction was carried out in 50mM Tris $\mathrm{HCl}, \mathrm{pH}$ 8.0. The main products 9,14-diHODE, 9,10-diHODE and 8,11-diHODE as well as the intermediate (9R)-HPODE are marked, peaks marked with a star represent products which were not identified so far. Unmarked peaks are endogenous substances of $E$. coli expression strain BL21. The experiment is representative for 15 independent experiments yielding similar results.

Figure 5 Identification of products of NspLOX conversion of LA. A, Mass spectrum and the corresponding fragmentation scheme of 9,14-diHODE. Stars mark those mass fragments that were identified and correspond to the proposed structure. B, Mass spectrum of 9,14diHODE derived from the conversion of LA in presence of ${ }^{18} \mathrm{O}_{2}$. C, Mass spectrum of 9,14diHODE derived from the conversion of LA in the presence of $\mathrm{H}_{2}{ }^{18} \mathrm{O}$. 
Figure 6 Free oxylipins of two cyanobacterial strains. The oxylipin levels were determined in control cells as well as in sonified cells. A, N. sp. PCC 7120 P (wt); B, SAG 25.82 (mt). The bars represent the values of detected hydroxy fatty acids from non treated (grey) or treated (black) cyanobacteria. Each value represents an average of three independent experiments, standard deviation is given. The insets show the CP-HPLC analyses for 9HODE in wt and mt strain, respectively. 


\section{Figure 1}

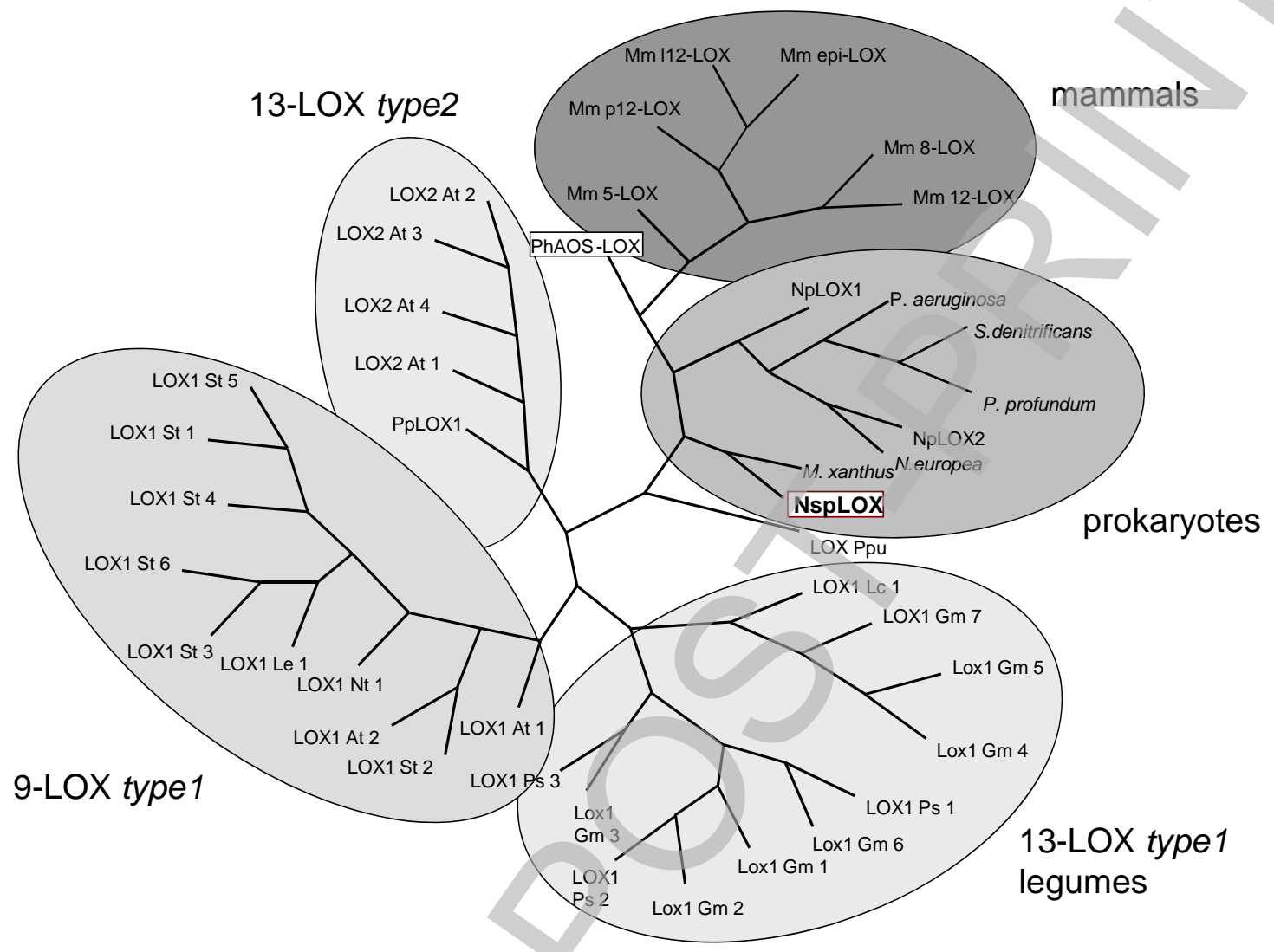

Licenced copy. Copying is not permitted, except with prior permission and as allowed by law. 
Figure 2

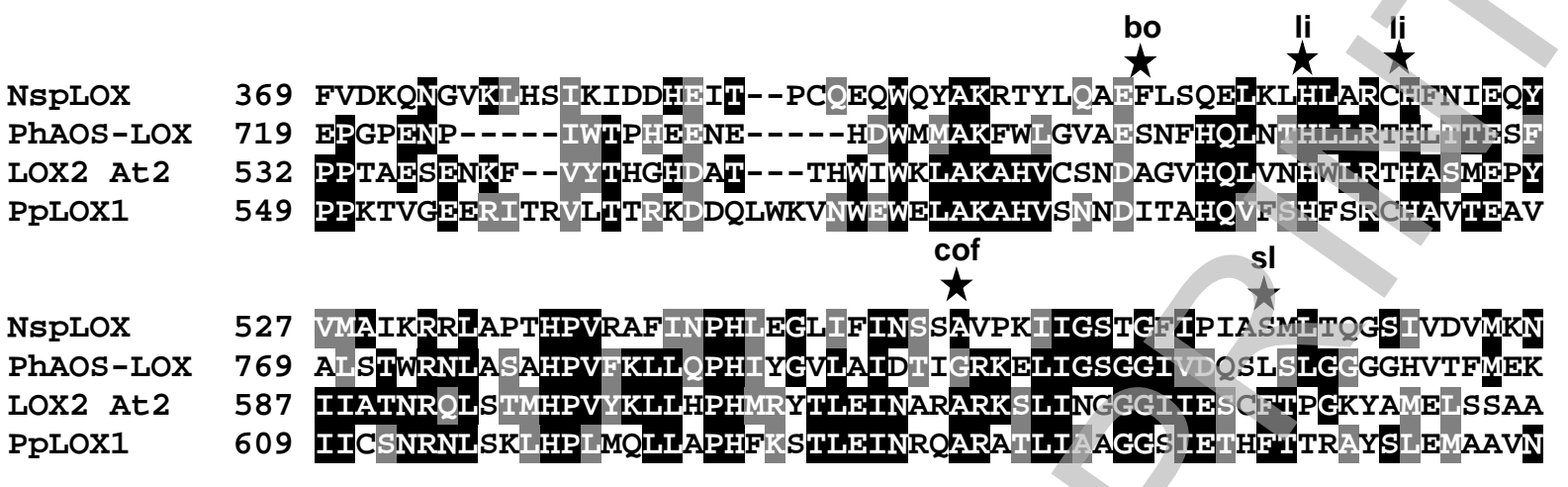

NspLOX 587 ELSKLSYMWNPT-ADLPRD - . . . . . . . . - IPGDLFTPAATAYWELLNNYVEQGL PhAOS-LOX 829 CFKEVNLQDYHLPNALKKRGVDDPSK - ........ LPG YYRDDGLALWEAIETFIGE-I L0X2 At2 647 YKSMWRFDMECLPADLVRRGMA EEDSSAEC GVRLVIDDYPYAADGLLTWKAIKDLVES- $Y$ PpL0X1 669 YKDTWTFESQALPTDLVARGMAVPDPDSPHGVRLVVEDYPYAADGLELWGALKAWHKE-Y

NspLOX 630 LQPFEDELRTEVNATQVDELFAELKER - . . - LYSGDQPPKYDSSE-LKSLLMYTIYH PhAOS-LOX 879 IAIFYKNDDDVKRDNEIQSWIYDVHKNGWRVNPGHQDHGVPASFESREQLKEVLTSLVFT L0X2 At2 706 VKHFYSDSKSITSDLELQAWWDEIKNKG---AYDKKDEPWWPKLNTTQDLSQILTNMIWI PpLOX1 728 VDIYYKDDAAVLQDSELMTWWTEMREKA- - HEDKKDSHGWPELNSKEALVDILTTVIWI

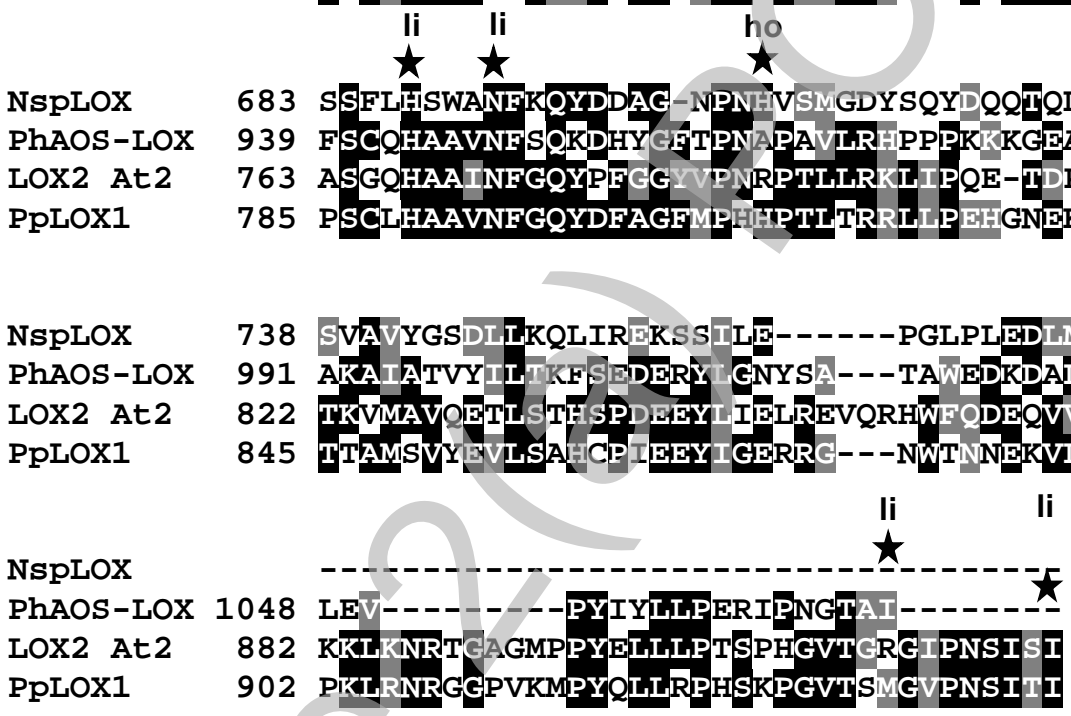




\section{Figure 3}

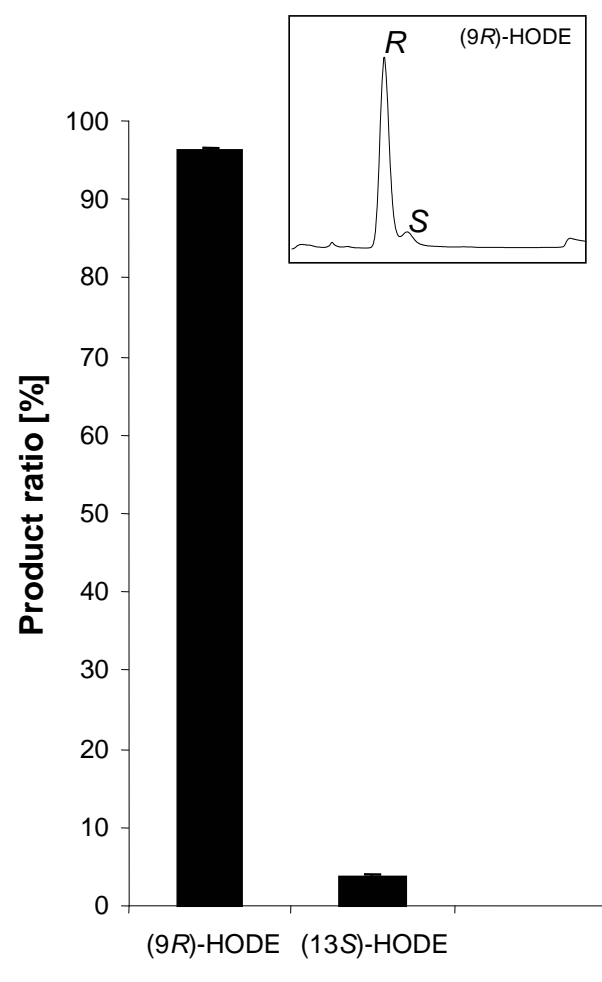

LA

ALA

AA 


\section{Figure 4}

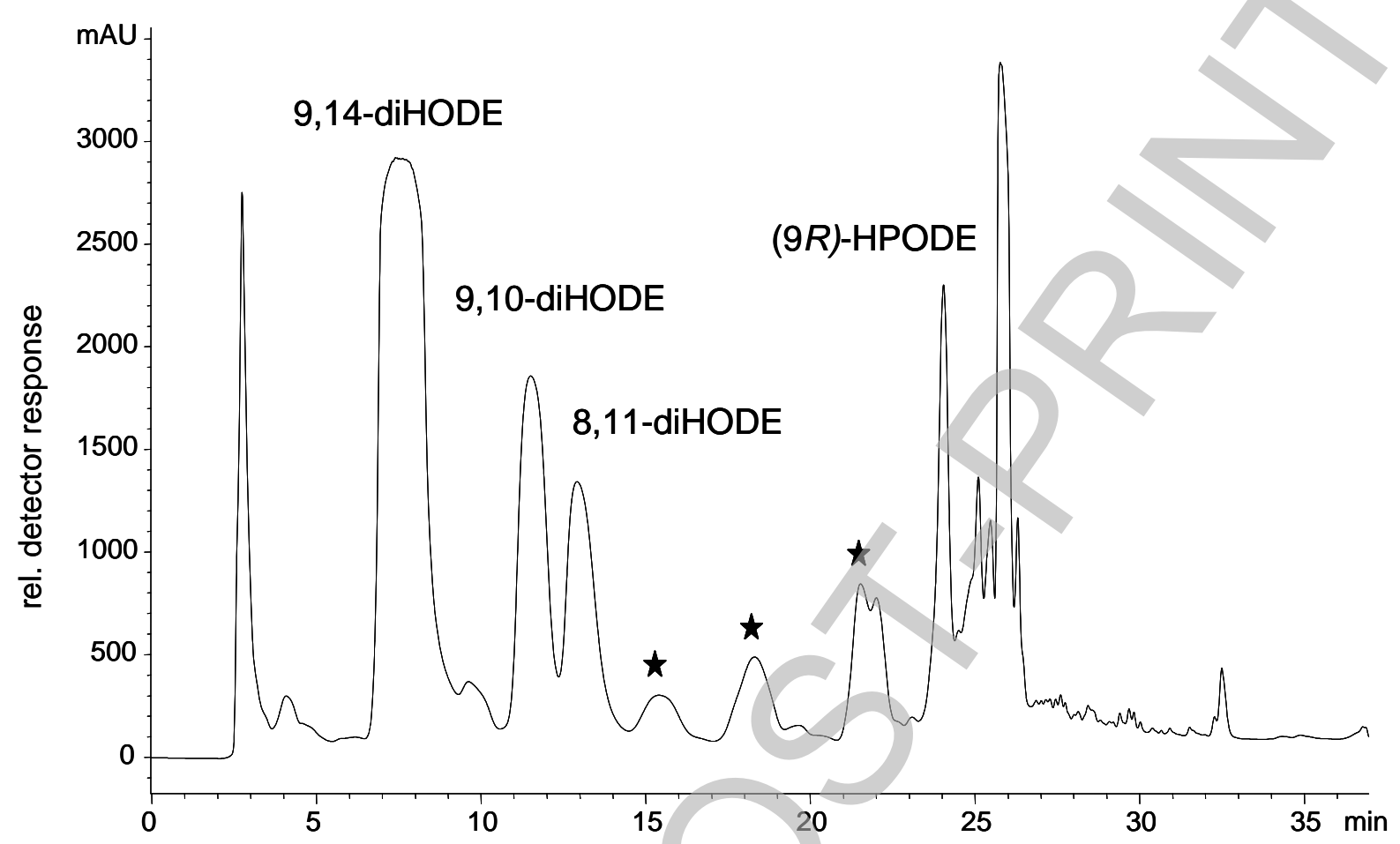

retention time 


\section{Figure 5}

A

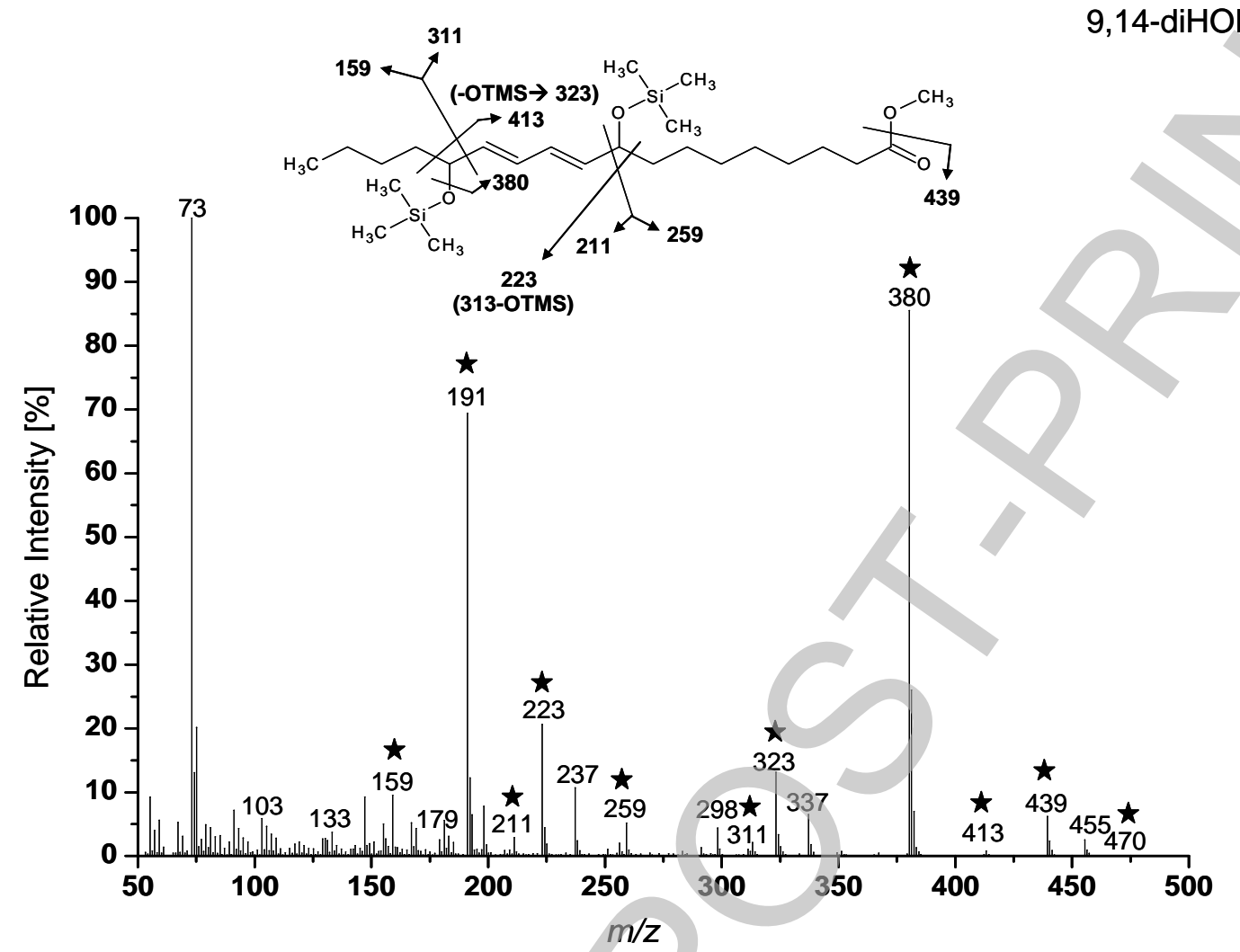

B

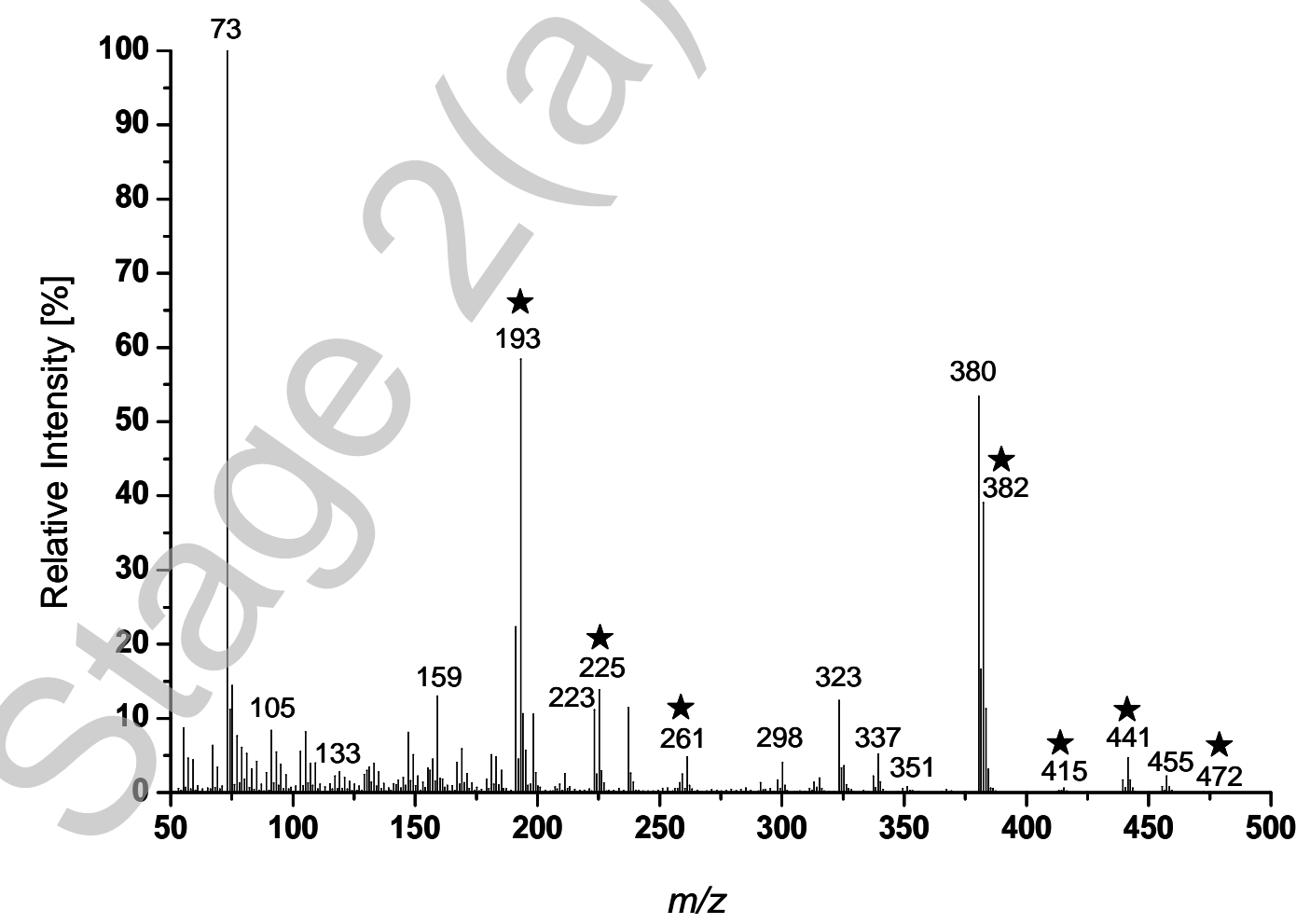

Licenced copy. Copying is not permitted, except with prior permission and as allowed by law.

(C) 2007 The Authors Journal compilation (c) 2007 Biochemical Society 
C

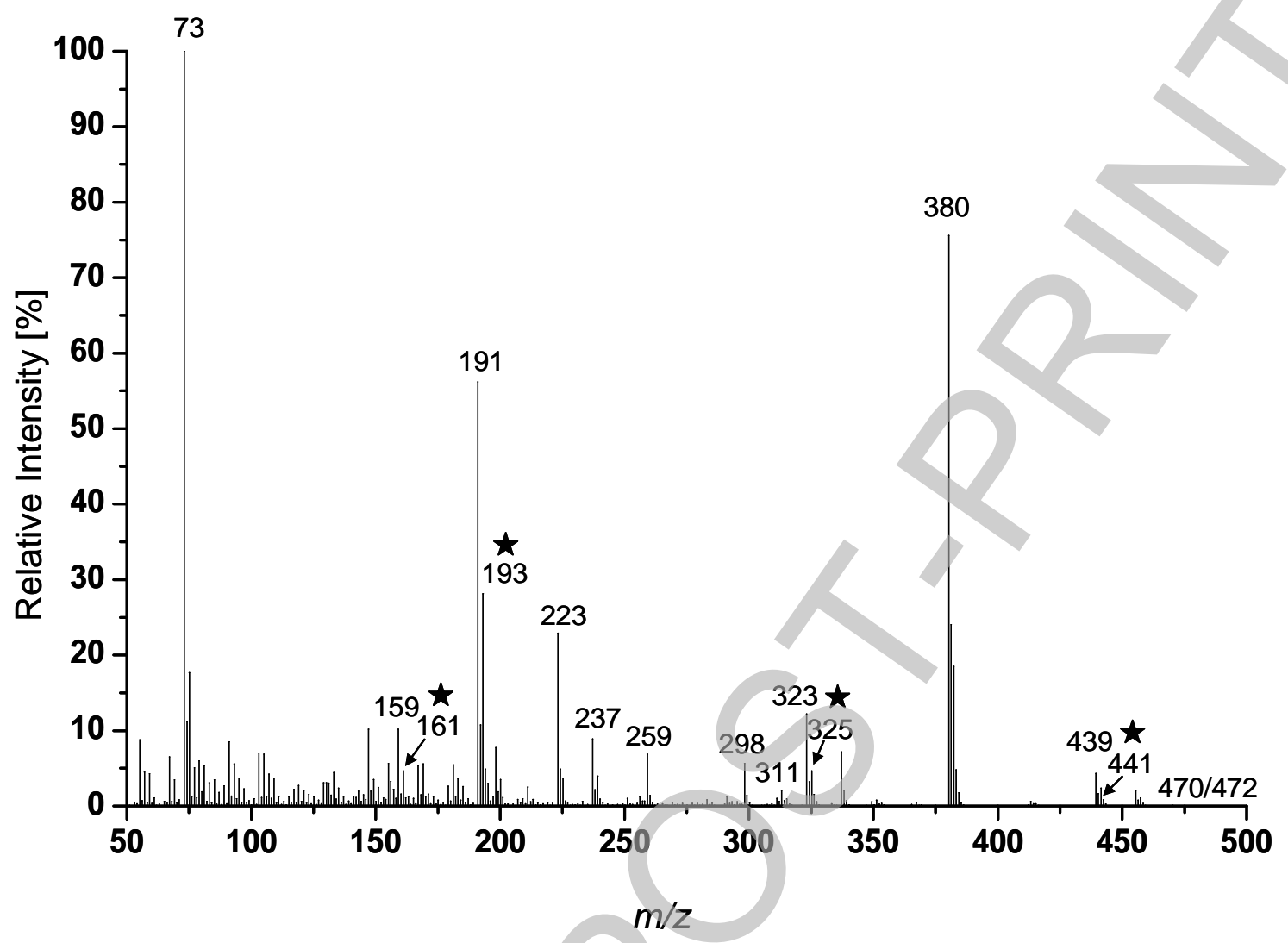




\section{Figure 6}

A

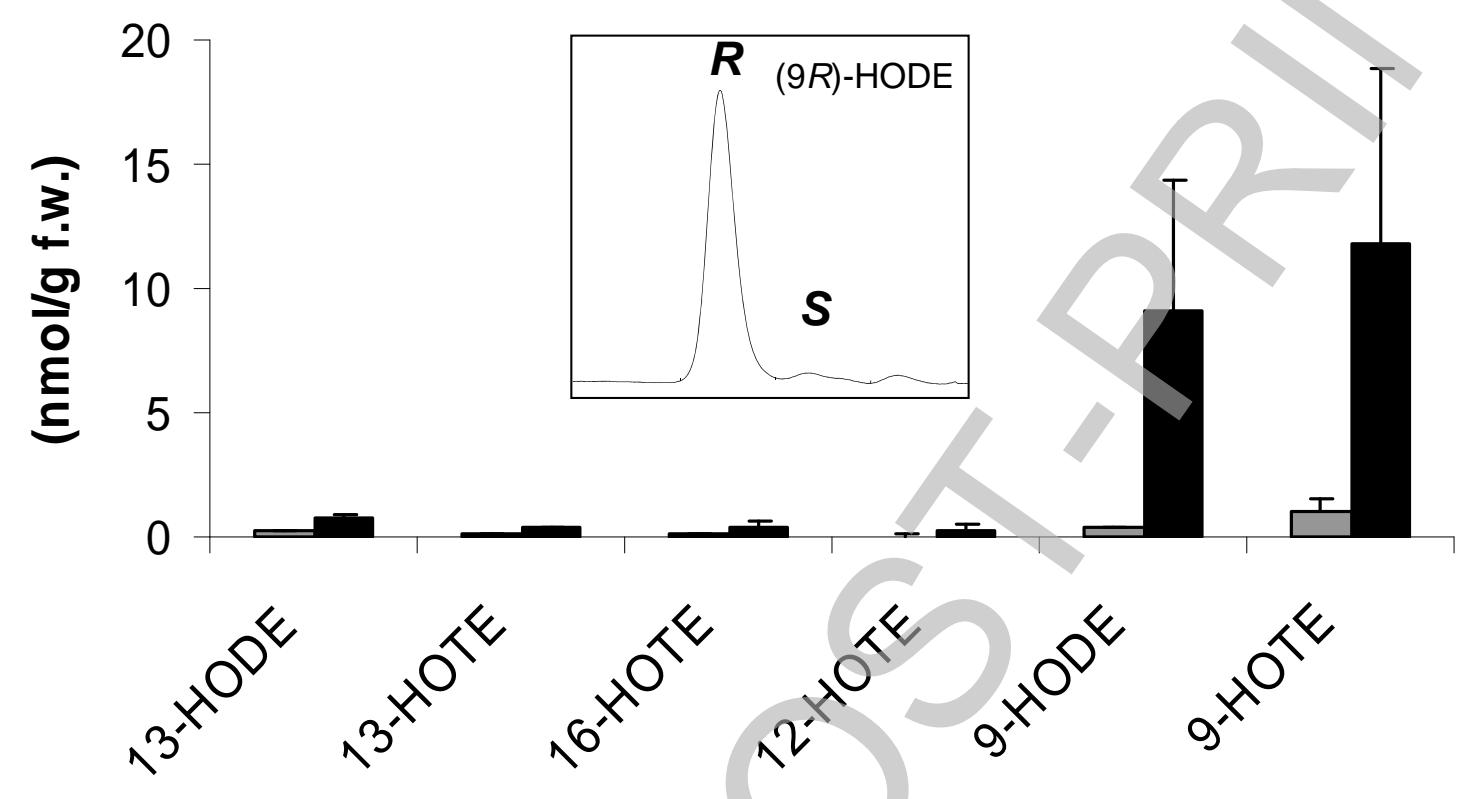

B

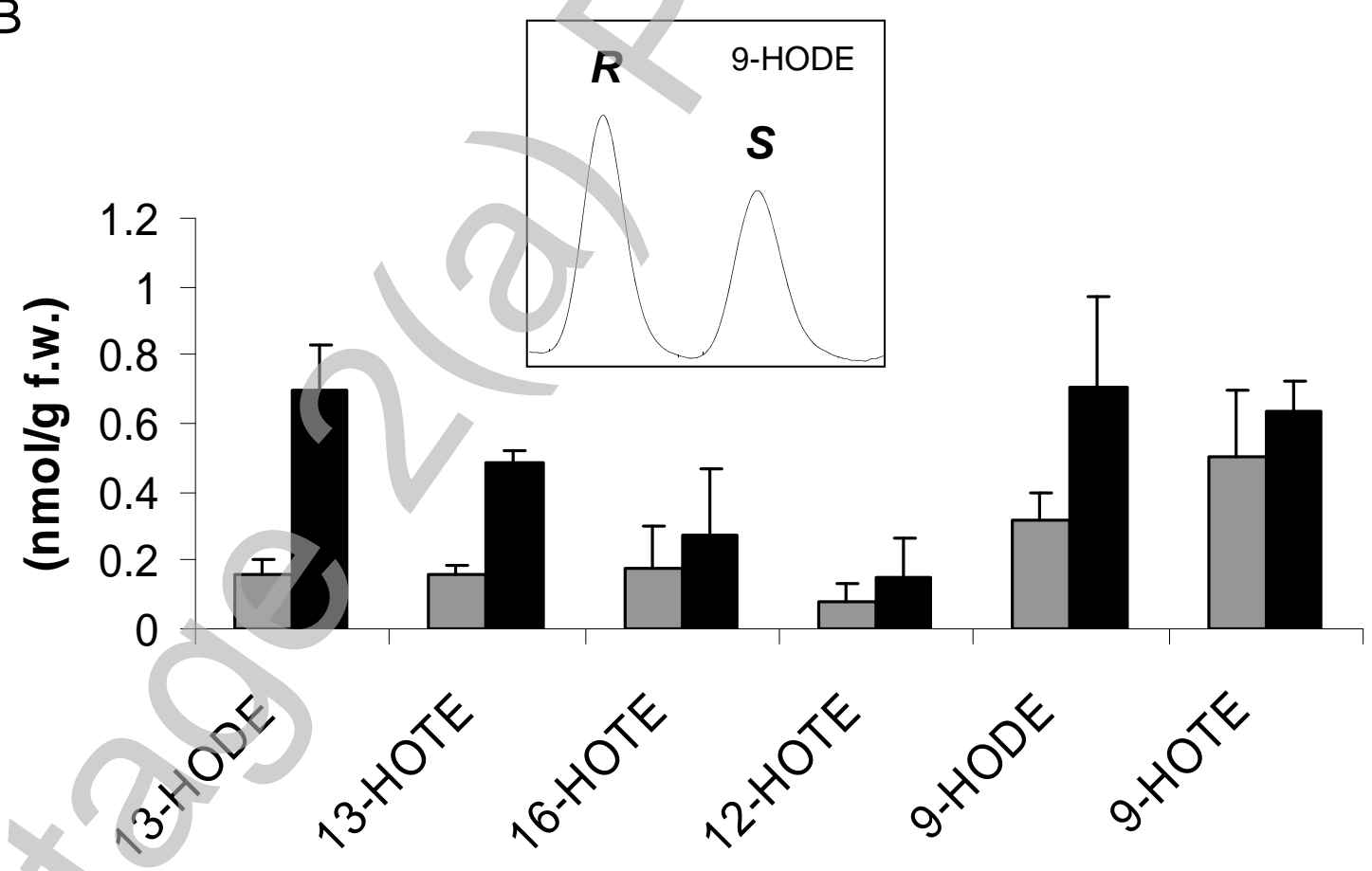

